\title{
Article \\ Transfer of Agricultural and Biological Sciences Research to Patents: The Case of EU-27
}

\author{
Mila Cascajares ${ }^{1}$ (D) Alfredo Alcayde ${ }^{1}$ (D) Esther Salmerón-Manzano ${ }^{2}$ and Francisco Manzano-Agugliaro ${ }^{1, * \mathbb{D}}$ \\ 1 Department of Engineering, University of Almeria, ceiA3, 04120 Almeria, Spain; milacas@ual.es (M.C.); \\ aalcayde@ual.es (A.A.) \\ 2 Faculty of Law, Universidad Internacional de La Rioja (UNIR), Av. de la Paz, 137, 26006 Logroño, Spain; \\ esther.salmeron@unir.net \\ * Correspondence: fmanzano@ual.es; Tel.: +34-950-015-346; Fax: +34-950-015-491
}

Citation: Cascajares, M.; Alcayde, A.; Salmerón-Manzano, E.; ManzanoAgugliaro, F. Transfer of Agricultural and Biological Sciences Research to Patents: The Case of EU-27. Agronomy 2021, 11, 252. https://doi.org/ 10.3390 /agronomy11020252

Academic Editor: Massimo Blandino Received: 31 December 2020

Accepted: 27 January 2021

Published: 29 January 2021

Publisher's Note: MDPI stays neutral with regard to jurisdictional claims in published maps and institutional affiliations.

Copyright: (c) 2021 by the authors. Licensee MDPI, Basel, Switzerland. This article is an open access article distributed under the terms and conditions of the Creative Commons Attribution (CC BY) license (https:/ / creativecommons.org/licenses/by/ $4.0 /)$.
Abstract: Agriculture as an economic activity and agronomy as a science must provide food for a constantly growing population. Research in this field is therefore becoming increasingly essential. Much of the research is carried out in academic institutions and then developed in the private sector. Patents do not have to be issued through scientific institutions. Patents from scientific institutions are intended to have a certain economic return on the investment made in research when the patent is transferred to industry. A bibliometric analysis was carried out using the Scopus and SciVal databases. This study analyses all the research carried out in the field of agronomy and related sciences (Agricultural and Biological Sciences category of Scopus database) by EU-27 countries, which has been cited in at least one international patent. The data show that out of about 1 million published works only about 28,000 have been used as a source of patents. This study highlights the main countries and institutions in terms of this transfer. Among these, Germany, France and Spain stand out in absolute terms, but considering the degree of specialization. Regarding their specialization the institution ranking is led by Swedish University of Agricultural Sciences (58\%), AgroParisTech (52\%), Wageningen University \& Research (48\%), and INRAE (38\%). It also analyses which journals used for this transfer are most important. For these publications more than $90 \%$ of the articles have had a higher-than-expected citation level for the year of publication, the type of publication and the discipline in which they are categorized. The most-obtained research fields can be distinguished as those related to genetics or mo-lecular biology, those related to specific foods, such as cheeses, milk, breads or oils, and, thirdly, the group covering food-related constituents such as caseins, probiotics, glutens, or starch.

Keywords: agronomy; SciVal; patents; Europe; bibliometrics; R\&D; Scopus; patentometrics; Triple Helix

\section{Introduction}

Agronomy is based on scientific and technological principles, and must study the physical, chemical, biological, economic, and social factors that, in one way or another, influence crop production [1]. Its fundamental basis is focused on studying human intervention in nature from an agro-productive point of view, or in other words, studying the agro-ecosystem as a specific model of human intervention in nature, with the aim of producing food and raw materials [2]. In short agronomy may be defined as the science of soil management and crop production [3].

The essential issue in agronomy is the study of the relationship between soil, plant, and environment, with the aim of maximizing yields, and reducing production costs, but doing so with responsibility and not at any price [4]. To do this, it is necessary to plan the processes, as well as to implement different measures to obtain the maximum use of natural resources, in order to produce more and improve production standards [5]. All this must be done paying special attention to non-renewable natural resources, which are in danger 
due to their negligent and uncontrolled use by man [6]. At this point, it is agronomy, which must be in charge of developing sustainable plans, for the efficient use of these resources, in order not to aggravate this situation, such as the case of water re-use in agriculture [7].

Agronomy also deals with the selection of suitable crop varieties, i.e., those best suited to the particular conditions of the environment $[8,9]$, as well as the adoption of the most effective production system [10], the choice of the most suitable growing techniques [11], the selection of appropriate plant protection measures [12,13], the adoption of the most efficient harvesting methods both in terms of quantity and quality [14,15], and the choice of the most appropriate post-harvest technologies $[16,17]$. This is done by considering the management of inputs, such as labor, seeds, fertilizers, facilities, and machinery [18].

Agronomy is certainly the fundamental basis of human nutrition [19]. The demographic pressure is increasing but the cultivation area remains static, therefore in order to feed the growing population it is necessary to exploit and maximize the yields of the production systems, and it is here that agronomy plays a fundamental role. Agronomy is a dynamic discipline, in continuous advance, which increases the knowledge of plants and their environment each day [20]. This leads to the development and implementation of new agricultural practices focused on fully exploiting the potential of the different production systems [21], as well as improving the production and processing processes of food from both a quantitative and qualitative point of view. In addition, agronomy must develop plans that enable integrated agricultural systems to be implemented, to achieve sustainable agricultural growth, that is to say without compromising the environment [22].

All these challenges are not possible without high-quality R\&D that is broad and multidisciplinary, and above all geographically distributed [23]. It is well known that public research usually allocates its large resources to basic research, while companies focus on applied research, which they can market either directly or by selling the knowledge they have developed [24]. Regarding this last point, the key is the protection of these rights, generally via patents [25].

It is a consensus in all industrialized countries that patent law has a decisive influence on the organization of the economy, as it is a key element in promoting technological innovation [26]. This last aspect is of the utmost importance, as it largely regulates business investment in R\&D. It should suffice to mention that one of the points to be reformed in the legislation of the applicant countries is the law governing patents when a country becomes a member of the European Union. For example, Spain's admission to the EU in 1986 led to the revocation of the 1929 patent law. European patent legislation is based on the Munich Convention of 5 October 1973 on the European Patent [27] and the Luxembourg Convention on the Community Patent of 15 December 1975 [28]. This European patent directive has been incorporated into almost all European patent legislation [29].

Without going into detail regarding European patent law, it should be noted that there are two categories of industrial property rights: patents for invention and utility models [30]. Patents give their holders a territorial right to prevent the commercial exploitation of the patented object without their consent for 20 years from the priority date, while for utility models this is limited to 10 years [31].

In short, patent laws must aim to promote the technological development of countries, starting from their industrial situation [32]. Particular attention has therefore been paid to the protection of national interests [33], especially by strengthening the obligations of patent holders so that the exploitation of patents takes place within their territory and a real transfer of technology takes place, but always in accordance with the Paris Union Convention of 20 May 1883, the text of which was revised in Stockholm on 14 July 1967 [34].

The issue of plant variety protection is particularly interesting. However, it is specified that a patent cannot be awarded for a particular variety of a plant or for essentially biological processes for obtaining plants such as crossing and selection. Some authors suggest that the right to patent agricultural innovations is increasingly placed in a political context [35]. 
Plant varieties can be protected by obtaining Plant Variety Protection (PVP) or Plant Variety Rights (PVR), provided that these varieties are new, distinct, uniform, and stable and have a name which is not liable to be confused with the names of other plants or with trademarks for Class 31 according to the Nice Classification [36].

In Spain, for example, the right obtained by entering the plant variety in the national register of commercial varieties does not correspond to this plant variety right but is distinct and complementary. To establish novelty there is a useful period of grace during which commercial acceptance can be verified. Plant variety titles grant their holder a territorial right to prevent the commercial exploitation of the variety without his consent for 30 years for vine, and potatoes varieties and tree species and 25 years for all other plant varieties, from the date the title is awarded [37].

In the plant breeding sector, patent protection of innovations is the prevalent strategy in the United States and China [38]. In Europe, however, plant breeders are choosing to protect new plant varieties [39]. According to the latest data provided by the International Union for the Protection of New Varieties of Plants (UPOV), the registration of plant varieties at the Community Office is the most widely used method worldwide, because it makes it possible to obtain protection in all EU Member States at a proportionately more attractive cost compared with the domestic route. The mission of UPOV is to provide and promote an effective system of plant variety protection, to encourage the development of new varieties of plants, for the benefit of society (https://www.upov.int/portal/index. html.en).

This article is organized as follows: first, a background section related to patentometrics and Triple Helix concept is introduced, then the data used and the methodology are described in the Materials and Methods section. The results are then analyzed and then discussed alongside other papers. This last section is organized as: global temporal trend; countries, affiliations, and collaborations; top journals used for the publications cited in patents; the quality of the articles; the open access and European funding agencies; topics of the publications cited in patents. Finally, the main conclusions of this research are drawn.

\section{Background: Patentometrics and Triple Helix}

Since the 2000s university patenting in the most advanced economies has been on the decline both as a percentage and in absolute terms [39]. We suggest that the institutional incentives for university patenting have disappeared with the new regime of university ranking, since patents or spin-offs are not counted in university rankings.

Patent statistics have long been of interest to innovation-conscious economists. The central question is whether or not patent statistics represent the real state of innovation [40]. The statistical analysis of patents can be named Patentometrics [41]. The first articles on this issue are quite recent, dating back to 2001 [40]. On the one hand, there are the statistics of the patents themselves, such as defining rank-ings for them based on citations [42], or as a patent h-index indicator to assess patenting quality [43]. A patent h-index has been introduced to evaluate the patenting activities of research organizations [44]. However, the h-index has been questioned for being insen-sitive to some exceptionally widely cited items, as can be seen from the large number of so-called h-indexes proposing to address this issue and to replace the original h-index; a review of these h-type indexes can be found in several studies, such as [45]. Patentometric indicators make it possible to quantify and qualify the performance of technological out-put on the basis of granted patents, e.g., in Brazil [46].

There is increasing interest in technology-based enterprises, for their capacity to contribute to economic and social development. To this end, patent-based indices have been developed with the aim of monitoring the impact of specific patents, or the state of technology in a given field, or comparing technology between countries. The comparative study between countries of patent production in a given field shows, according to some researchers, how advanced a technology is in the countries that are leaders in this field, and is called the specialisation index [47]. Therefore, the information contained in patent 
documentation has become one of the principal techniques for modeling technology scenarios for government, business and industry, research institutes or projects, [48]. Most of this work is based on patent databases such as United States Patent and Trademark Office (USPTO) [17] or European Patent Office (EPO), but one alternative that has proved to be valid and open access is Google Patents (www.google.com/patents), which includes over 8 million full-text patents $[49,50]$.

Patenting is not only a significant method of university knowledge transfer, but also an important indicator for measuring academic R\&D strength and knowledge utilization [43]. Because patents are a direct output of innovative activities, cross-border patents are used to analyze the trend of global collaborative creativity [51]. Usually two sets of documents, impact articles and patents have been used as approximation measures to analyze the research of the institutions, and in this way both the trajectories of the scientific and technical front are analyzed, and then the research into these can be categorized as basic science or applied technology [52]. e.g., Brazil, scientometric and patentometric indicators have been studied to assess the non-financial criteria associated with technology for the purposes of financial funding, as there is a growing interest in technology-based companies due to their ability to contribute to economic and social development [53]. Another issue of great relevance is the assessment of scientific publications and patent analysis production. This enables the definition of the growth rate of scientific and technological output in terms of the top countries, institutions and journals producing knowledge within the field as well as the identification of main areas of research and development [41].

A modern and competitive economic model needs science, as well as a strong public R\&D system, funded in a stable way, and aligned with economic development. Science is gradually advancing towards a technological orientation rather than a theoretical orientation [54]. Triple Helix, is an academic theory that argues that the potential for development of the knowledge economy in regions or countries lies in the close collaboration of companies, universities and governments based on new institutional formulas designed for the production, transfer and application of knowledge. The theory of the triple helix introduced and developed by Etzkowitz and Leydesdorff [55] follows the same line, highlighting the role of government along with the other two helixes: universities and industry [56]. This is because innovation processes, as well as research and innovation policy decision-making processes, tend to increasingly involve the variety of components of the innovation system, i.e., academia, industry and stakeholders who are the end-users.

A triple helix model to study university-industry-government relationships is based on indicators such as: webometric, scientometric and technometric [55]. Patent-based metrics could be utilized in a Triple Helix context, and hybrid indicators could be developed by combining a patent with other data [55]. Most of the patented academic inventions are related to scientific research and are financed by public funds. These tend to be used in large companies rather than in start-ups founded by academic entrepreneurs [56]. Moreover, some studies show that scientific excellence and technology transfer activities are mutually reinforcing [57], so it is important to understand their relationship.

The first step in this context is to define the indicators, and then to establish a benchmarking framework. The European Commission has elaborated an evaluation re-port in this regard to benchmark the five aspects: human resources in RTD; public and private investment in RTD; scientific and technological productivity; impact of RTD on economic competitiveness and employment; promotion of RTD culture and public under-standing of science. These indicators are based on \% of GDP or per million population.

In relation to agriculture, the Triple Helix model is not well studied, but it is worth noting the work done in this field in Korea and China, where they used bibliometric indi-cators. The raw inputs were the numbers (or \%) of manuscripts with only academic au-thors, only industry authors, only government authors, only authors who are from aca-demia or industry, etc. [58].

Previous studies have focused only on the evolution of new technologies through the study of patents and have rarely explored the context of prior knowledge, i.e., the research 
on which these patents are based. The aim of this paper is therefore to analyze the potential contribution of research in the EU-27 countries as a driving force for technological innovation in the field of agricultural and biological sciences. To this end, bibliometric indicators will be used to analyze all the works published in this scientific field by the EU-27 countries that are cited in at least one patent. The Europe of 27 (EU27) is made up of the following countries: Austria, Belgium, Bulgaria, Croatia, Cyprus, Czech Republic, Denmark, Estonia, Finland, France, Germany, Greece, Hungary, Ireland, Italy, Latvia, Lithuania, Luxembourg, Malta, Netherlands, Poland, Portugal, Romania, Slovakia, Slovenia, Spain, and Sweden. Finally, the aim is to launch a visualized model that can be applied, as a tool for analyzing any scientific field in any country or group of countries, where the degree of transfer of the research carried out can be measured by means of patent citation. The Europe of 27 (EU27) is made up of the following countries: Austria, Belgium, Bulgaria, Croatia, Cyprus, Czech Republic, Denmark, Estonia, Finland, France, Germany, Greece, Hungary, Ireland, Italy, Latvia, Lithuania, Luxembourg, Malta, Netherlands, Poland, Portugal, Romania, Slovakia, Slovenia, Spain, and Sweden.

\section{Materials and Methods}

Science can be considered as what is published in scientific journals [59]. Scientific databases therefore play a key role in the progress of science since what has been published previously is the basis for new research. Within the existing scientific databases, Web Of Science (WOS) and Scopus can be considered to have leading positions in most branches of knowledge. There are many research studies that indicate that Scopus covers at least $80 \%$ of the content of the WOS database. Scopus has been used in considerable bibliometric studies in many branches of knowledge, such as those of Engineering [60], Environmental Science [61] or Agricultural and Biological Sciences [62,63].

To carry out this study, the publications in the scientific field of Agricultural and Biological Sciences indexed in Scopus in the period 1999-2019 in the geographical area of the European Union (the current 27 EU countries) were analyzed. Of the data obtained, the study focuses on those publications that have been cited at least once in patents. This limitation was made with SciVal; a tool closely linked to Scopus.

As one of the most important reference databases in the field of research, Scopus indexes around 25,000 journal titles from more than 5000 publishers. Although its contents date back to 1788, it was not until 1996 that these contents became the basis of SciVal, Elsevier's tool for metric analysis. SciVal provides access to the scientific output of more than 230 countries and 14,000 institutions. SciVal therefore makes it possible to visualize research performance, make comparisons, analyze trends, and evaluate collaborations [64]. As an analysis tool, SciVal has been employed in several publications, applying the metrics provided by this tool. e.g., studies on the progress of thermal spraying research were carried out between 1985 and 2015 [65,66] and supplemented by SciVal. Additionally, in 2016 Yu et al. [67] used SciVal in a comparison metric analysis with ResearchGate. In the domain of research in medical radiation science, Ekpo, Hogg and McEntee [68] analyzed international collaboration and institutional activity with metrics obtained from SciVal. Or as last example, the analysis of research results from Russian universities was also based on SciVal conducted in 2018 [69], and recently in 2019, a bibliometric analysis of big data was carried out using SciVal [70].

To achieve the direct download of data from Scopus and SciVal, the Scopus API Key was used, by means of this API it is possible to obtain more data than from a direct download (https:/ / dev.elsevier.com/sc_apis.html). To visualize the results, Microsoft Excel was used as an analysis tool by means of dynamic tables and ArcGIS for the representation of the map.

Using these two tools, the data were obtained by carrying out two searches. See Figure 1 for an outline of the methodology. The first was in Scopus, of publications between 1999 and 2019, in the scientific field of Agricultural and Biological Sciences, in the EU27; the second in SciVal, of publications between 1999 and 2019, in the scientific field of 
Agricul-tural and Biological Sciences, in the EU-27, and which have been cited in patents. To ob-tain data on publications cited in patents, the bibliometric indicator "Patent-Cited Schol-arly Output" was selected for all publication types and for all patent offices. SciVal offers coverage of five of the largest patent offices: European patent office (EPO), US Patent Office (USPTO), UK Intellectual Property Office (UK IPO), Japan Patent Office (JPO) and World Intellectual Property Organization (WIPO) [71].

\section{Get all Papers}

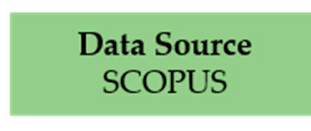

Search Criteria Subject Area AGRI Data 1999-2019 Country EU27

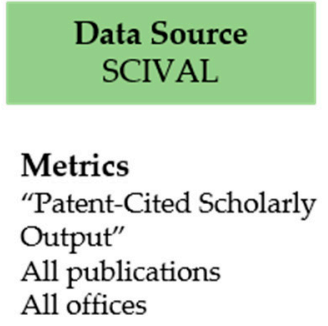

All offices

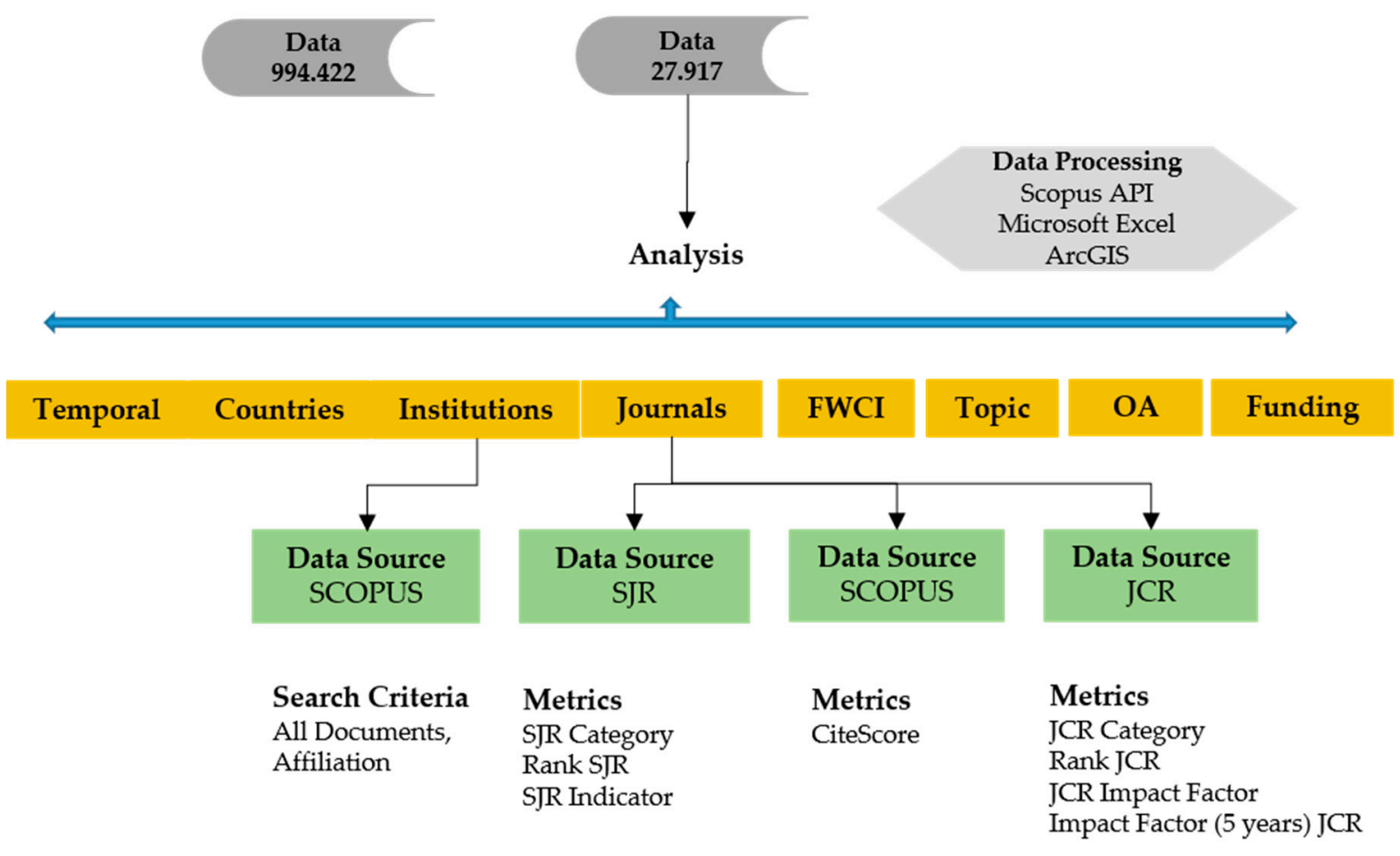

Figure 1. Methodology flowchart.

In order to establish the degree of specialization of institutions, an indicator called degree of specialization (ESP-AGRI) has been developed. The ESP-AGRI indicator shows the degree of specialization of the institution with respect to this scientific category. This indicator calculates the percentage of publications of the analyzed subject with respect to the total number of publications (N-AGRI) of a given institution.

To complete the analysis of the data, bibliometric indicators were obtained referring to the impact of the Top 20 journals in which the greatest number of papers have been published according to the search carried out. Thus, on the one hand, the indicators related to Scopus were extracted: SJR Category, Rank SJR, SJR Indicator and CiteScore, and, on the other hand, they were completed with the impact indicators of the other database referring to research, WOS-Journal Citation Reports (JCR). From JCR, JCR Category, Rank JCR, JCR Impact Factor and Impact Factor (5 years) JCR were extracted. These values were obtained by searching in JCR, SJR and Scopus. 
SJR and JCR classify journals based on different categories within a certain scientific field, assessing the position within the category based on the total number of journals classified in that category, resulting in the quartile in which they are positioned within the category.

The SJR Indicator and JCR Impact Factor measure the quality of scientific publications based on the citations obtained in each publication. Both indicators are calculated by dividing the citations in the year being evaluated (in our case 2019) to articles published in previous years by the total number of articles and reviews published in that period. The difference between both indicators is that the SJR Indicator considers the three previous years, making the citation range is three years, while the JCR Impact Factor considers two years of citation. Based on the obtained result, it is possible to establish a ranking of journals that allows for determination of their quality.

At the end of 2016 [72], Scopus established a new indicator to measure the impact of a publication, CiteScore. Like the previous indicators, it measures the ratio of citations per article published in a given journal but extends the citation range to four years and includes citations of a larger typology of documents (articles, reviews, conference proceedings, book chapters and data documents) published on Scopus in that 4-year period.

Finally, the Impact Factor (5 years) JCR, shows the average number of times articles from the journal have been cited in the JCR year, from published in the last five years. The calculation is like the previous indicators; it is obtained by dividing the number of citations in the JCR year by the total number of articles published in the previous five years.

Citation as a basis for assessing the impact of publications has its roots in Eugene Garfield who developed the concept of the available citation index [73]. Both the JCR Impact Factor and the SJR Indicator provide a numerical value that needs to be interpreted in terms of several factors. The main consideration is the number of citations, which is directly linked to the area of research, the year of publication and the type of publication. Despite being the most widely used index in many bibliometric studies, the JCR Impact Factor is also the most discussed index because of its limitations such as asymmetry between numerator and denominator, differences between disciplines, insufficient citation range and the asymmetry of underlying citation distributions [74]. On the other hand, the SJR index tries to rectify these deviations by weighting the links based on the closeness of the citation, extending the number of years considered in the citation and setting thresholds for selfcitation within the journal itself [75]. The CiteScore index also extends the range of years in the citation, but, although by including all types of documents the differences between the different types of documents are eliminated, some critics say that this index favors Elsevier's pub-lications, which tend to publish a higher proportion of types document other than articles than other publishers [76].

Regarding affiliations, Scopus has been the database used most often to calculate the percentage of publications indexed between 1999 and 2019 in the scientific field of Agricultural and Biological Sciences with respect to the total publications of the top 20 institutions that have published in the field. For this purpose, the total number of publications in the affiliation (documents, affiliation only) was considered.

On the other hand, it has been considered important to make an analysis of the research topics reflected in the publications that have been cited in patents. The Agricultural and Biological Sciences field covers many different subjects and SciVal uses the Topics to identify the predominant topics of interest. A Topic includes a set of documents with a common interest. They are clustered within SciVal based on direct citation analysis. Document reference lists are used for this purpose, so that a document can belong to only one Topic. However, as newly published documents are indexed, they are added to the Topics using their reference lists. This makes the Topics dynamic and most of them increase in size over time.

Topics with similar research interests are grouped into Topic Clusters forming broader research areas and, in both concepts, Topic and Topic Cluster, prominence can be measured by two parameters: the Topic Prominence Percentile and the Topic Cluster Prominence 
Percentile. In both measures, prominence is calculated by SciVal by considering the number of citations received in the year with respect to citations received in the same and previous year, the number of views in Scopus in the year of publications in that and previous year, and the average number of citations in CiteScore in the year [77]. Prominence is therefore an indicator of the visibility and momentum of a given Topic, which is why it is important to analyze the percentage of publications in the Top20 journals that are in the first percentile (Top 10\%). Note that these are indicators provided by the SciVal database.

While the Topics help us to see how visible the publications have been, it is the FieldWeighted Citation Impact (FWCI) that allows us to determine whether the publication has reached the level of citation that was expected of it. The FWCI considers the year of publication, the type of publication and the discipline in which it is categorized, so that if the FWCI value does not reach the benchmark we can say that it has not exceeded the prospects set for that publication. The benchmark is 1: a score equal to this or above it means that expectations were met in terms of citation; a score below it means they were not.

Since this study is based on the Europe of 27, it was considered interesting to analyze the sources of funding for research that are cited in patents. In this sense, together with other funding agencies, we wanted to see the role of European Commission through the different Research Framework Programs that were developed in this period (1999-2019): Fifth Framework Program 1998-2002 (FP5), Sixth Framework Program 2002-2006 (FP6), Seventh Framework Program (FP7) 2007-2013 and Horizon 2020 (H2020) 2014-2020.

Since the Budapest Declaration in 2002, there have been many public statements promulgating open access to scientific production without copyright restrictions. The European Commission itself requires open access publication of the results of research funded under its Framework Programs. Therefore, another element considered in this study is the impact of Open Access (OA).

\section{Results and Discussion}

For the search criteria in the Scopus database, and for the whole of the EU-27 in the Agricultural and Biological Sciences category, 994,422 records were obtained, while, for the same category in the SciVal database, and with the criterion of having been cited in at least one patent, there were 27,917 records.

\subsection{Global Temporal Trend}

Figure 2 shows the evolution of articles published by the EU-27 countries in the category of Agricultural and Biological Sciences (N-AGRI) from 1999 to 2019. It can be seen that in the last 8 years they have stabilized at just over 65,000 publications.

Furthermore, the evolution of the studies cited in patents (N-AGRI-CP) is shown, and until 2012, the articles cited stabilized at around 1500 studies. Research conducted in oth-er disciplines shows that the last 10 years of publications are not very significant in terms of citations by patents [78].

The series of data shown in Figure 2, up to 2009, shows great stability in the publications cited in patents. However, the relevant fact is that, at the beginning of the series, in 1999 , publications cited were $6 \%$ of the total, but this figure slowly decreased to $3 \%$ of the total in 2010. This means that the research effort in relation to technological transfer and patents, has fallen by half in 10 years, from 1999 to 2009. The average overall transfer for the EU-27 countries for this period (1999-2009) was 5\%.

Regarding EU funding, the different framework programs have had a positive impact on the increase in publications in the field under study, except for H2020, which seems to remain at the level reached in the previous scenario. 


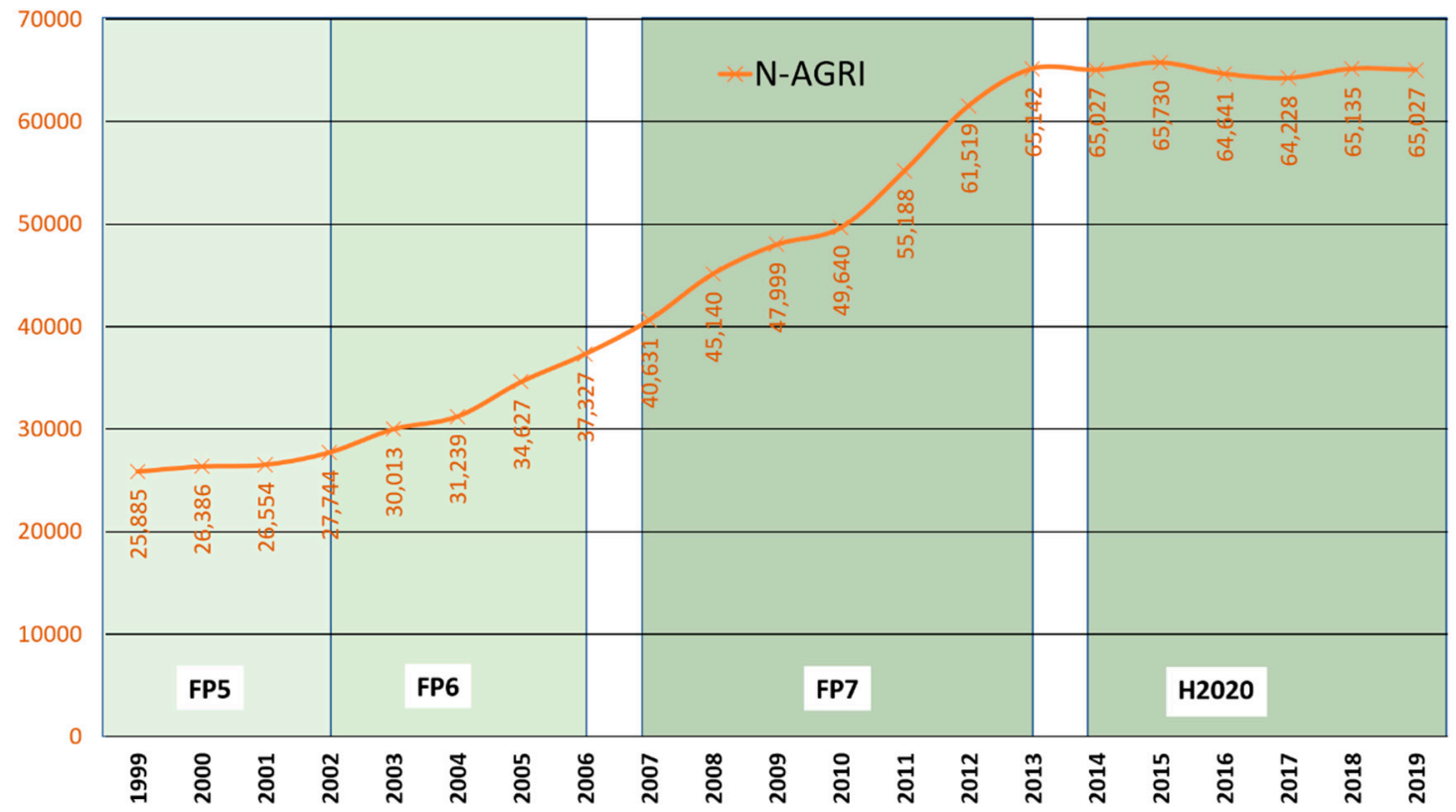

A

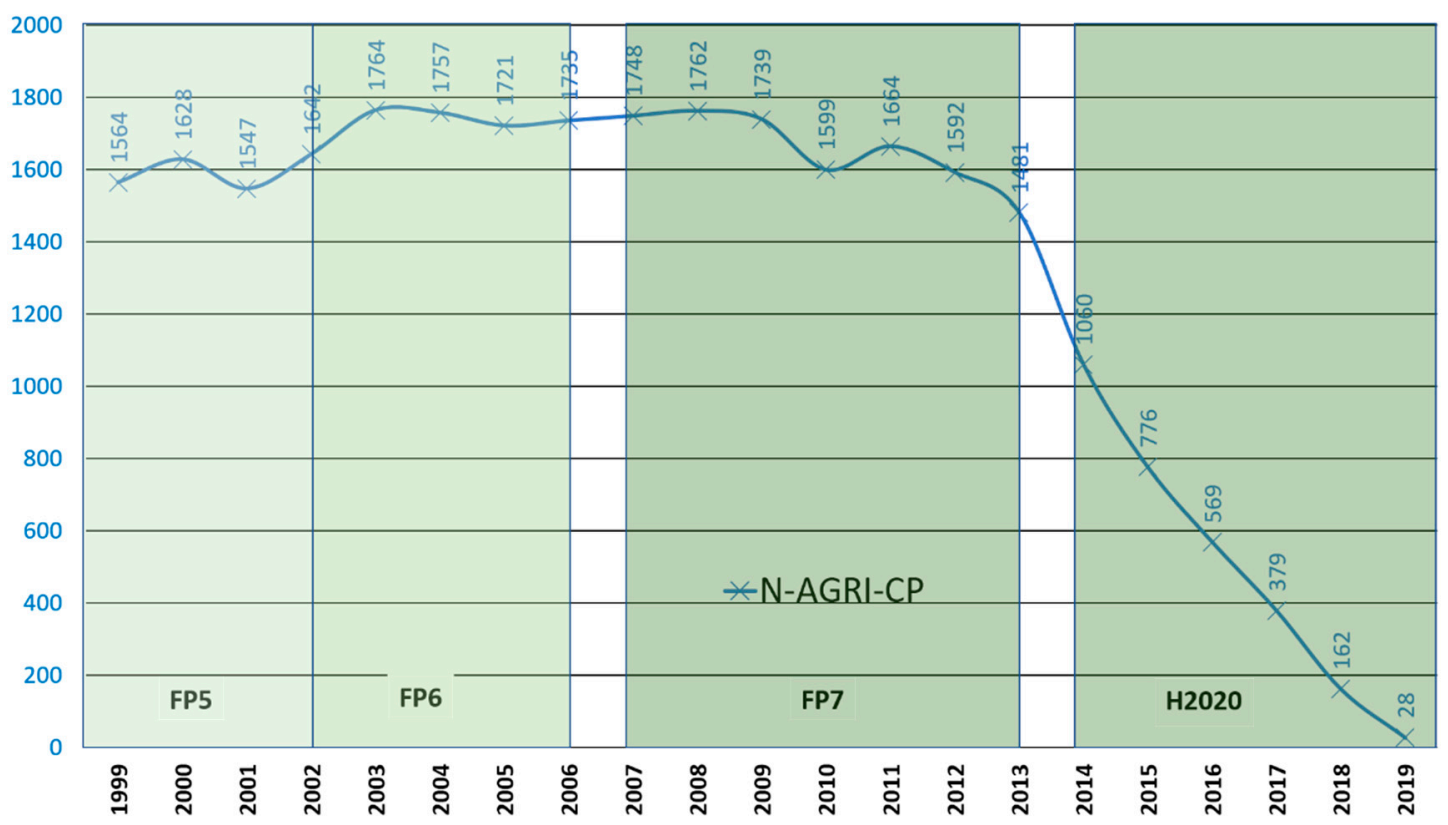

Figure 2. Agricultural and Biological Sciences publications: (A) total publication in Europe 27 (EU-27) (N-AGRI), (B) cited by international patents (N-AGRI-CP).

\subsection{Countries, Affiliations, and Collaborations}

In this section, publication data are counted for each of the authors of a publication when establishing countries, affiliations, and collaborations. This is the system used by the Scopus and SciVal databases. Figure 3 shows both the scientific production of the EU-27 countries in green, and the scientific collaboration with the other countries of the world in red. The higher color intensity indicates higher scientific production or collaboration with the EU-27. Of all these works, $40 \%$ are international collaborations with another 130 countries. These collaborations are mainly with the United States (4123), the United Kingdom (2373), Switzerland (878), Canada (707), Australia (586), Japan (520), China (465), Brazil (263), Israel (256), and Norway (255). This list of countries is not surprising as they are generally countries with a high research capacity, especially in the field of agricultural 
sciences. Others, such as Switzerland and Norway, have a geographical proximity to the EU-27, which makes them natural partners.

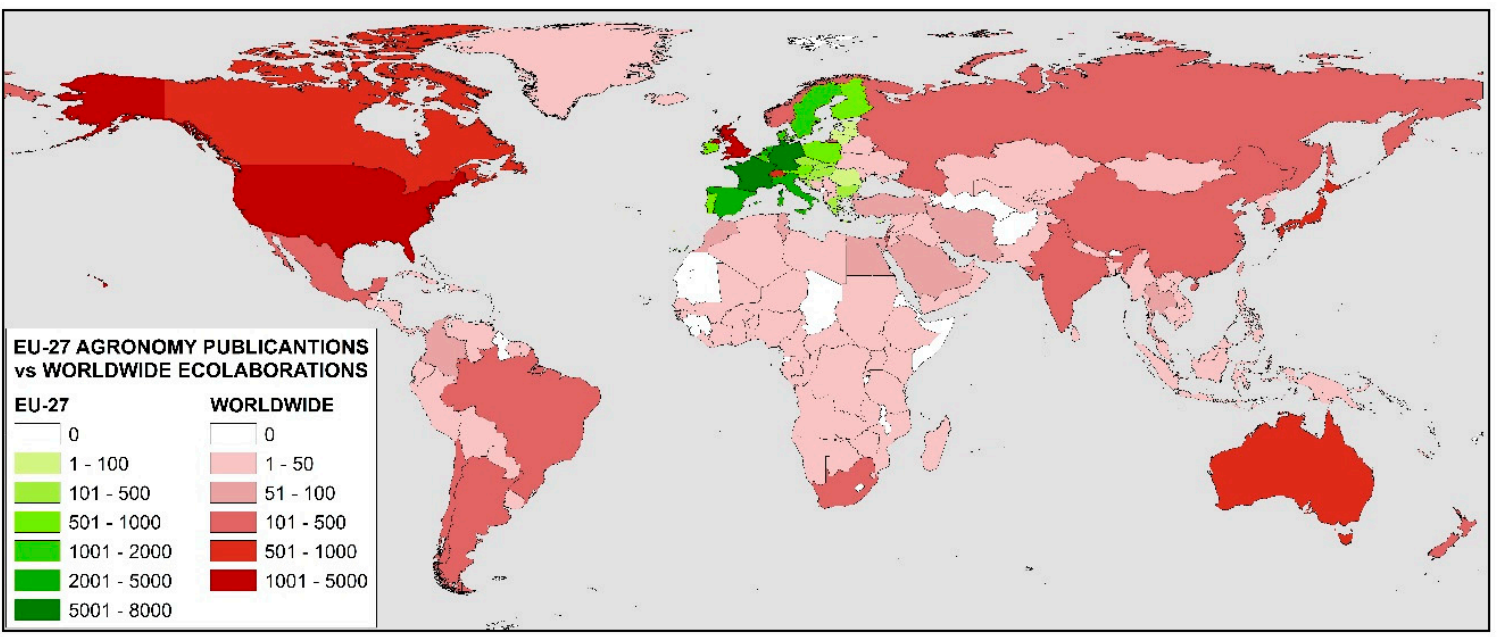

Figure 3. Worldwide production and collaboration of EU-27 publications cited in patents.

In Figure 4 the distribution by country of the scientific production in Agricultural and Biological Sciences that is cited in patents is shown. It is led by Germany with more than 7000 studies, followed by France with more than 5000, and in third place Spain with more than 3000 . This list of outstanding countries continues with the Netherlands and Belgium with more than 2000 publications.

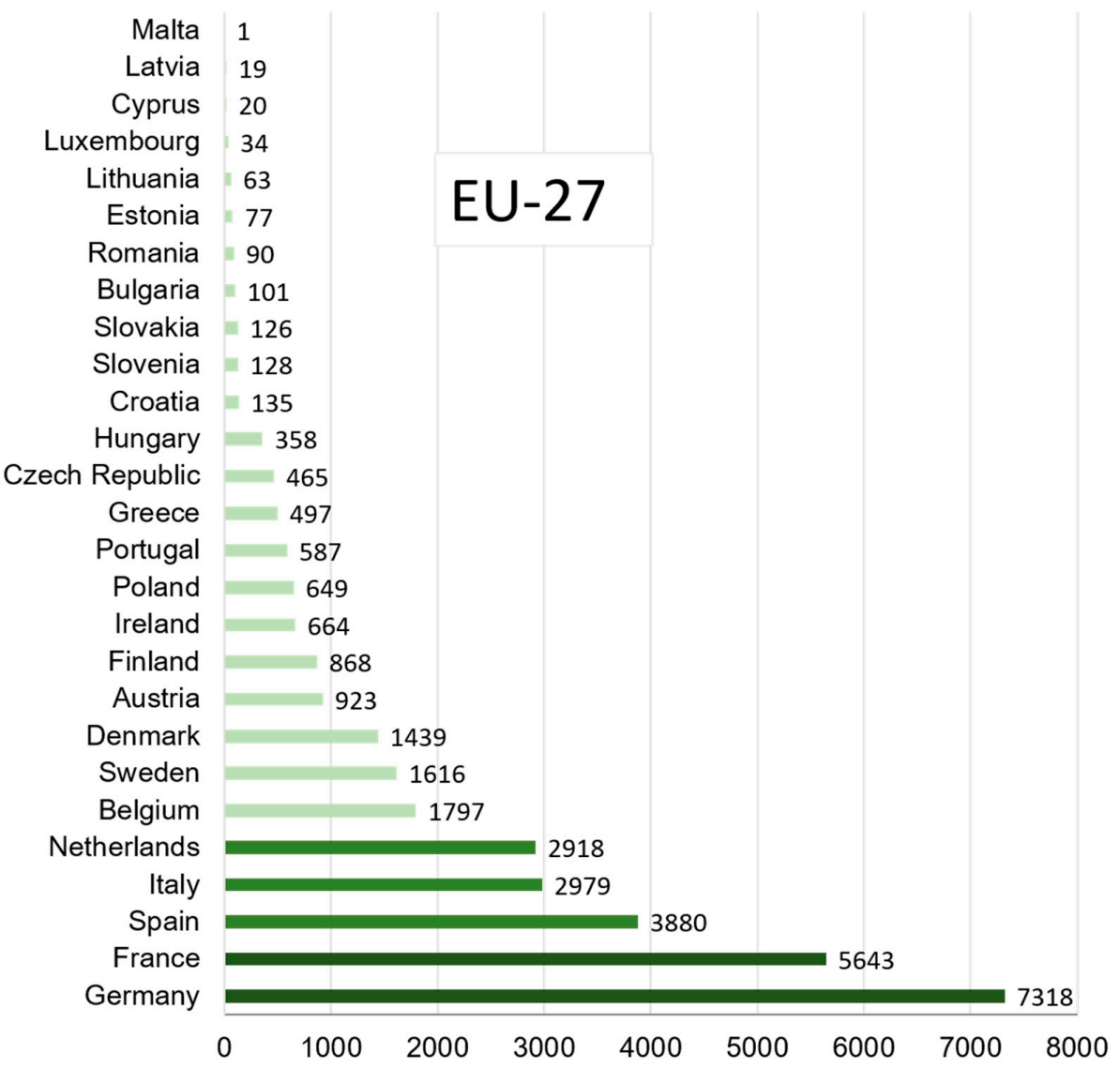

Figure 4. EU-27 publications cited in patents. 
The research carried out by the countries is carried out in specific institutions, which are the real leaders in this research. Table 1 shows the top 20 institutions. This table reflects both the total works published by each institution in this period $(\mathrm{N})$ and those in the category studied (N-AGRI), and of these those that were cited in patents (N-AGRI-CP). The ESP-AGRI indicator shows the degree of specialization of the institution with respect to this scientific category. The TIP-AGRI indicator measures the level of transfer of an institution, the relationship between publications indexed in the Agricultural and Biological Sciences category and publications that have been cited in patents.

Table 1. Agricultural and Biological Sciences Transference Index in Patents (TIP-AGRI).

\begin{tabular}{|c|c|c|c|c|c|}
\hline Institutions & N-AGRI-CP ${ }^{1}$ & N-AGRI $^{2}$ & $\mathbf{N}^{3}$ & ESP-AGRI $^{4}(\%)$ & TIP-AGRI $^{5}(\%)$ \\
\hline CNRS & 2804 & 39,395 & 411,402 & 9.58 & 7.12 \\
\hline INRAE & 2092 & 6356 & 16,563 & 38.37 & 32.91 \\
\hline CSIC & 1458 & 22,974 & 110,344 & 20.82 & 6.35 \\
\hline Wageningen University \& Research & 1189 & 26,883 & 56,370 & 47.69 & 4.42 \\
\hline $\begin{array}{l}\text { Institut National de la Santé et de la } \\
\text { Recherche Médicale }\end{array}$ & 884 & 8304 & 177,215 & 4.69 & 10.65 \\
\hline Université Paris-Saclay & 734 & 6086 & 95,202 & 6.39 & 12.06 \\
\hline Ghent University & 683 & 14,620 & 94,557 & 15.46 & 4.67 \\
\hline University of Copenhagen & 662 & 15,892 & 99,175 & 16.02 & 4.17 \\
\hline National Research Council of Italy & 442 & 14,586 & 139,335 & 10.47 & 3.03 \\
\hline Swedish University of Agricultural Sciences & 437 & 15,912 & 27,592 & 57.67 & 2.75 \\
\hline KU Leuven & 434 & 9573 & 120,699 & 7.93 & 4.53 \\
\hline Technical University of Munich & 415 & 8138 & 104,312 & 7.80 & 5.10 \\
\hline Université de Montpellier & 368 & 8414 & 49,926 & 16.85 & 4.37 \\
\hline University of Helsinki & 366 & 13,856 & 84,064 & 16.48 & 2.64 \\
\hline Sorbonne Université & 365 & 11,111 & 122,422 & 9.08 & 3.29 \\
\hline Utrecht University & 362 & 8114 & 73,306 & 11.07 & 4.46 \\
\hline AgroParisTech & 346 & 5693 & 11,001 & 51.75 & 6.08 \\
\hline Technical University of Denmark & 340 & 6801 & 65,011 & 10.46 & 5.00 \\
\hline Universidad Autónoma de Madrid & 340 & 5991 & 72,892 & 8.22 & 5.68 \\
\hline Institut Pasteur Paris & 296 & 2459 & 22,126 & 11.11 & 12.04 \\
\hline
\end{tabular}

${ }^{1}$ N-AGRI-CP Total number of publications classifies as Subject area Agricultural and Biological Sciences (ASJC) cited in patents. ${ }^{2}$ N-AGRI Total number of publications published by the institution in period 1999-2019 classifies as Subject area Agricultural and Biological Sciences (ASJC). ${ }^{3} \mathrm{~N}$ Total number of publications published by the institution in period $1999-2019 .{ }^{4} \mathrm{ESP}-\mathrm{AGRI}=\mathrm{N}-\mathrm{AGRI} \times 100 / \mathrm{N}$. ${ }^{5} \mathrm{TIP}-\mathrm{AGRI}=$ N-AGRI-CP $\times 100 /$ N-AGRI.

From the data in Table 1, there are only three institutions specializing in this scientific category, considering those that have more than $30 \%$ of their scientific production in it. This specialization is led by Swedish University of Agricultural Sciences (58\%), AgroParisTech (52\%), Wageningen University \& Research (48\%), and INRAE (38\%). The other institutions have a degree of specialization that is quite far away, between 4 and $20 \%$.

The high level of transfer can be verified as oscillating from 2 to $33 \%$ of the total of works published in this category by each one of these institutions. In this regard, it is important to note that, as can be seen, eight institutions in France are in the top 20. It should be noted that the average overall transfer for the EU-27 countries for the period 1999-2009 was 5\%. There are 10 institutions above 5\%, and it should be remembered that the entire series is studied here, from 1999 to 2019, where transfer in the last 10 years was low until the technology or research is adopted by the industry.

The Institut National de Recherche en Agriculture, Alimentation et Environnement (INRAE) in France has a transfer rate of 33\%, with a level of specialization of its publications of $38 \%$. The case of Université Paris-Saclay (France) is also noteworthy, with a trans-fer rate of $12 \%$ despite the low level of specialisation of its publications (6\%); the same can be seen with the Institut National de la Santé et de la Recherche Médicale (France), with a transfer of $11 \%$ and a specialization of less than $5 \%$, and, finally, Institut Pasteur Paris, with $12 \%$ transfer rates versus $11 \%$ specialization. A curious situation is that of 
the two institutions that are mentioned as highly specialized, but have a low level of transferL Swedish University of Agricultural Sciences (2\%), and Wageningen University \& Research (4\%).

Regarding international collaboration, three institutions stand out in particular, United States Department of Agriculture (308), Harvard University (258), and University of Oxford (207).

\subsection{Top Journals Used for the Publications Cited in Patents}

Table 2 lists the top 20 journals in which these patent-cited works have been published. These 20 journals account for 14,217 articles out of the total 27,917, which is half of the publications (50.93\%). The mega-journal PLos ONE stands out in terms of the number of publications with 3379 articles. In 2014 Binfield [43] defined the four main criteria for a mega-journal: a very broad thematic scope, scientific solvency of the article, open access generally through article processing charges (APC) and a broad editorial board of academic publishers. Under these four criteria, PLos ONE appeared in 2006. Since its launch, its number of publication increased until it reached its maximum in 2013 with 32,055 documents indexed in Scopus, from this moment on the number of documents indexed in Scopus has decreased, reaching 16,316 in 2019. Categorized in both SJR and JCR as Multidisciplinary, it is positioned in the first quartile in SJR while moving to the second quartile in JCR.

Taking SJR as a reference, all the journals are positioned in at least one of their categories in the first quartile. However, if positioning in JCR is analyzed, of the Top 20 journals studied, three do not reach a position in the first quartile. To the already mentioned PLos ONE, one must add European Food Research and Technology and International Journal of Systematic and Evolutionary Microbiology.

The dominant categories in SJR are Plant Science and Genetics, with seven journals indexed in these categories, followed by Food Science and Medicine (miscellaneous), with six journals in each category. In JCR, the Plant Science category, eight journals are indexed, and in Food Science and Technology, six journals are indexed. From an editing perspec-tive, nine of the Top 20 Journals were published in the United States, and the re-maining eleven were published in European countries: United Kingdom, Netherlands, and Germany.

SciVal employs the All Science Journal Classification (ASJC) categories to classify Scopus sources, i.e., journals. Note that the same journal can be assigned one or more categories of the ASJC classification. The following field names are classified under the subject area Agricultural and Biological Sciences:

- $\quad$ Agricultural and Biological Sciences (all)

- Agricultural and Biological Sciences (miscellaneous)

- Animal Science and Zoology

- Agronomy and Crop Science

- Aquatic Science

- Ecology, Evolution, Behavior, and Systematics

- Food Science

- Forestry

- Horticulture

- Insect Science

- Plant Science

- Soil Science 
Table 2. Top 20 journals and their metrics. (Data 2019).

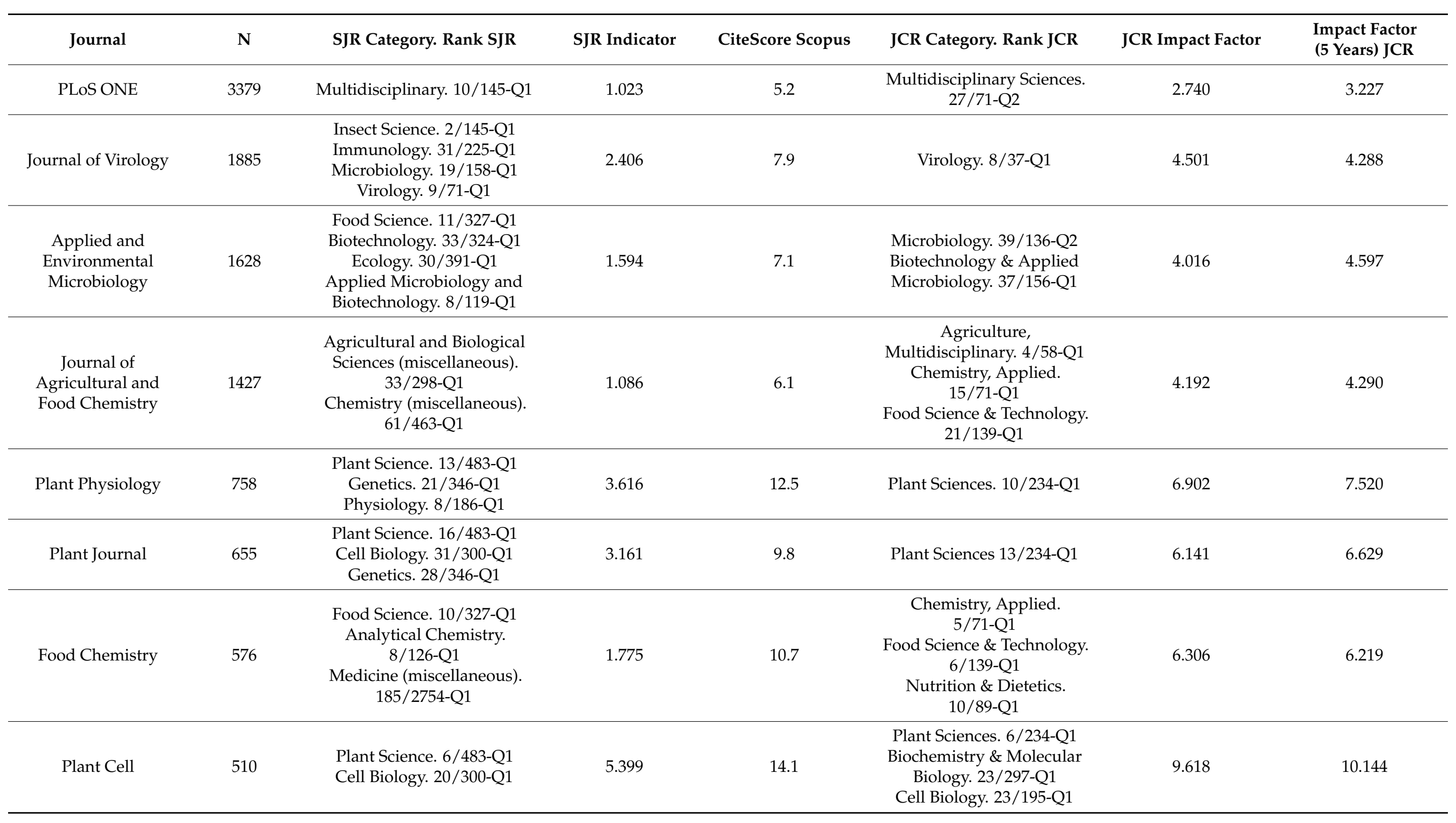


Table 2. Cont.

\begin{tabular}{|c|c|c|c|c|c|c|c|}
\hline Journal & $\mathbf{N}$ & SJR Category. Rank SJR & SJR Indicator & CiteScore Scopus & JCR Category. Rank JCR & JCR Impact Factor & $\begin{array}{l}\text { Impact Factor } \\
\text { (5 Years) JCR }\end{array}$ \\
\hline $\begin{array}{c}\text { Journal of } \\
\text { Experimental Botany }\end{array}$ & 343 & $\begin{array}{c}\text { Plant Science. 19/483-Q1 } \\
\text { Physiology. 15/186-Q1 }\end{array}$ & 2.647 & 9.8 & Plant Sciences. 14/234-Q1 & 5.908 & 7.011 \\
\hline $\begin{array}{l}\text { International Journal } \\
\text { of Food Microbiology }\end{array}$ & 327 & $\begin{array}{c}\text { Food Science. 22/327-Q1 } \\
\text { Safety, Risk, Reliability and } \\
\text { Quality. 13/394-Q1 } \\
\text { Microbiology. 37/158-Q1 } \\
\text { Medicine (miscellaneous). } \\
\text { 298/2754-Q1 }\end{array}$ & 1.364 & 7.4 & $\begin{array}{c}\text { Microbiology. 35/136-Q2 } \\
\text { Food Science \& Technology. } \\
\text { 23/139-Q1 }\end{array}$ & 4.187 & 4.226 \\
\hline Phytochemistry & 323 & $\begin{array}{c}\text { Horticulture. 9/90-Q1 } \\
\text { Plant Science. 106/483-Q1 } \\
\text { Biochemistry. 208/456-Q2 } \\
\text { Molecular Biology. } \\
\text { 255/414-Q3 } \\
\text { Medicine (miscellaneous). } \\
\text { 821/2754-Q2 }\end{array}$ & 0.763 & 4.9 & $\begin{array}{c}\text { Plant Sciences. 47/234-Q1 } \\
\text { Biochemistry \& Molecular } \\
\text { Biology. 155/297-Q3 }\end{array}$ & 3.044 & 3.374 \\
\hline $\begin{array}{c}\text { Plant Molecular } \\
\text { Biology }\end{array}$ & 308 & $\begin{array}{c}\text { Agronomy and Crop Science. } \\
\text { 11/363-Q1 } \\
\text { Plant Science. 27/483-Q1 } \\
\text { Genetics. 66/346-Q1 } \\
\text { Medicine (miscellaneous). } \\
\text { 191/2754-Q1 }\end{array}$ & 1.730 & 7.6 & $\begin{array}{c}\text { Plant Sciences. 42/234-Q1 } \\
\text { Biochemistry \& Molecular } \\
\text { Biology. 138/297-Q2 }\end{array}$ & 3.302 & 4.065 \\
\hline Current Biology & 301 & $\begin{array}{c}\text { Agricultural and Biological } \\
\text { Sciences (miscellaneous). } \\
\text { 4/298-Q1 } \\
\text { Biochemistry, Genetics and } \\
\text { Molecular Biology } \\
\text { (miscellaneous). 17/271-Q1 } \\
\text { Neuroscience (miscellaneous). } \\
\text { 0/151-Q1 }\end{array}$ & 3.958 & 13.8 & $\begin{array}{c}\text { Biology. 3/93-Q1 } \\
\text { Biochemistry \& Molecular } \\
\text { Biology. 24/297-Q1 } \\
\text { Cell Biology. 24/195-Q1 }\end{array}$ & 9.601 & 10.174 \\
\hline
\end{tabular}


Table 2. Cont.

\begin{tabular}{|c|c|c|c|c|c|c|c|}
\hline Journal & $\mathbf{N}$ & SJR Category. Rank SJR & SJR Indicator & CiteScore Scopus & JCR Category. Rank JCR & JCR Impact Factor & $\begin{array}{l}\text { Impact Factor } \\
\text { (5 Years) JCR }\end{array}$ \\
\hline $\begin{array}{l}\text { Theoretical and } \\
\text { Applied Genetics }\end{array}$ & 290 & $\begin{array}{c}\text { Agronomy and Crop Science. } \\
\text { 3/363-Q1 } \\
\text { Biotechnology. 23/324-Q1 } \\
\text { Genetics. 54/346-Q1 } \\
\text { Medicine (miscellaneous). } \\
\text { 154/2754-Q1 }\end{array}$ & 1.968 & 7.2 & $\begin{array}{c}\text { Agronomy. 5/91-Q1 } \\
\text { Plant Sciences. 18/234-Q1 } \\
\text { Genetics \& Heredity. } \\
\text { 37/178-Q1 } \\
\text { Horticulture. 2/36-Q1 }\end{array}$ & 4.439 & 4.603 \\
\hline $\begin{array}{l}\text { Journal of Dairy } \\
\text { Science }\end{array}$ & 287 & $\begin{array}{c}\text { Animal Science and Zoology. } \\
\text { 10/429-Q1 } \\
\text { Food Science. 17/327-Q1 } \\
\text { Genetics. 88/346-Q2 }\end{array}$ & 1.440 & 5.4 & $\begin{array}{c}\text { Agriculture, Dairy \& Animal } \\
\text { Science. 5/63-Q1 } \\
\text { Food Science \& Technology. } \\
\text { 37/139-Q1 }\end{array}$ & 3.333 & 3.432 \\
\hline $\begin{array}{l}\text { Journal of Food } \\
\text { Engineering }\end{array}$ & 276 & Food Science. 23/327-Q1 & 1.338 & 7.5 & $\begin{array}{c}\text { Engineering, Chemical. } \\
\text { 28/143-Q1 } \\
\text { Food Science \& Technology. } \\
\text { 16/139-Q1 }\end{array}$ & 4.499 & 4.332 \\
\hline $\begin{array}{l}\text { European Food } \\
\text { Research and } \\
\text { Technology }\end{array}$ & 264 & $\begin{array}{c}\text { Food Science. 88/327-Q2 } \\
\text { Biochemistry. 237/456-Q3 } \\
\text { Biotechnology. 107/324-Q2 } \\
\text { Chemistry (miscellaneous). } \\
\text { 123/463-Q2 } \\
\text { Industrial and Manufacturing } \\
\text { Engineering. 85/484-Q1 }\end{array}$ & 0.654 & 3.8 & $\begin{array}{l}\text { Food Science \& Technology. } \\
\text { 58/139-Q2 }\end{array}$ & 2.366 & 2.341 \\
\hline Planta & 253 & $\begin{array}{c}\text { Plant Science. 50/483-Q1 } \\
\text { Genetics. 107/346-Q2 }\end{array}$ & 1.259 & 5.4 & Plant Sciences. 41/234-Q1 & 3.390 & 3.687 \\
\hline PLoS Genetics & 223 & $\begin{array}{c}\text { Ecology, Evolution, Behavior } \\
\text { and Systematics. 15/663-Q1 } \\
\text { Cancer Research. 17/214-Q1 } \\
\text { Genetics. 19/346-Q1 } \\
\text { Molecular Biology. 29/414-Q1 } \\
\text { Genetics (clinical). 7/99-Q1 }\end{array}$ & 3.744 & 9.0 & $\begin{array}{c}\text { Genetics \& Heredity. } \\
\text { 26/178-Q1 }\end{array}$ & 7.528 & 8.555 \\
\hline $\begin{array}{l}\text { International Journal } \\
\text { of Systematic and } \\
\text { Evolutionary } \\
\text { Microbiology }\end{array}$ & 204 & $\begin{array}{c}\text { Ecology, Evolution, Behavior } \\
\text { and Systematics. 122/663-Q1 } \\
\text { Microbiology. 56/158-Q2 } \\
\text { Medicine (miscellaneous). } \\
\text { 504/2754-Q1 }\end{array}$ & 1.020 & 4.2 & Microbiology. 86/136-Q3 & 2.415 & 2.415 \\
\hline
\end{tabular}


Using the above classification, it is possible to establish which field names the stated publications were classified under. Note that the indexing of articles in the scientific categories is done by the indexing category of the journal. This information is provided direct-ly by Scopus; see Figure 5. In this case, Scopus indexes the work into the scientific catego-ries as the journal it is published in is indexed. Three different groups can be clearly seen: the three that are around 20\% (Food Science, Plant Science, Agricultural and Biolog-ical Sciences (all)), those that are 5-10\% (Agronomy and Crop Science, Insect Science, Ecology, Evolution, Behavior and Systematics, Animal Science and Zoology) and those that are below 3\% (Horticulture, Aquatic Science, Soil Science, Forestry, Agricultural and Biological Sciences (miscellaneous)). Therefore, the transfer in patents is mainly led by the field of food science, followed by plant science. The first three categories together account for almost $60 \%$ of all these publications (59.3\%).

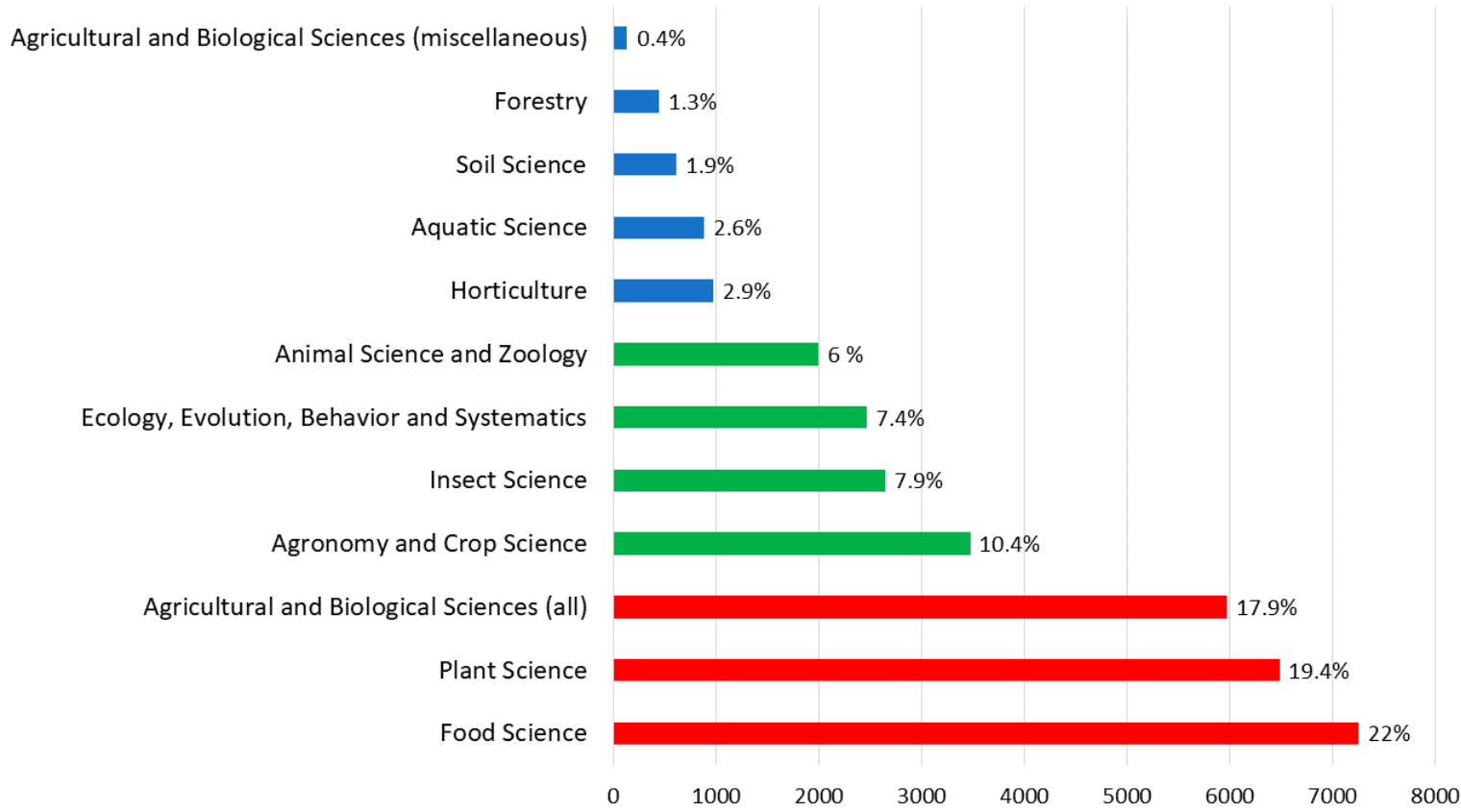

Figure 5. Field names for ASJC on Agricultural and Biological Sciences.

Of all the papers published in journals, 2020 of them were review papers, forming $7.3 \%$ of the total. Note that the review works are only $3.4 \%$ of the total scientific production of this category. This means that they are very important studies in the patent field, as they reflect the state-of-the-art in a particular field and provide a context for the patent. Finally, it should be mentioned that all these publications have an average of six authors. This should, therefore, be the number considered as the average number of authors for papers in this scientific field.

\subsection{The Quality of the Articles}

The journal's quality criteria do not measure the quality of individual articles published in that journal. A journal can publish articles of excellent quality that may be overlaid by others of lesser quality, resulting in an overall count that determines the final quality of the journal. The Field-Weighted Citation Impact (FWCI) allows the quality of an article to be measured, so that if its value equals or exceeds the value 1, the article has exceeded the citation expectation for that article.

This section only analyses data from articles cited in patents (N-AGRI-CP). Figure 6 shows how, in four of the Top 20 of journals with the highest transference, more than $90 \%$ of the published articles equaled or exceeded the FWCI's benchmark of 1 . This means that more than $90 \%$ of the articles have had a higher-than-expected citation level for the year of publication, the type of publication and the discipline in which they are categorized. 
Plant Cell stands out, with $98.2 \%$ of its articles with a value equal to or greater than 1 . Five jour-nals have a value equal to or greater than the benchmark for between 80 and $89 \%$ of their articles. Seven do so for $70-79 \%$ of their articles. Of the top 20, the lowest value is $50.8 \%$ of the articles in the European Food Research and Technology journal.

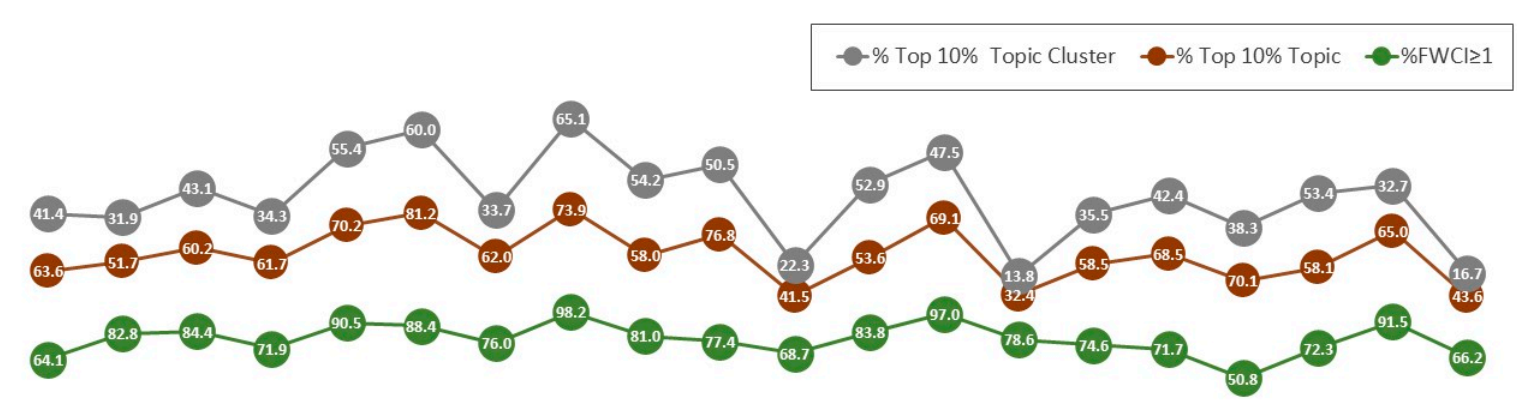

\begin{tabular}{|c|c|c|c|c|c|c|c|c|c|c|c|c|c|c|c|c|c|c|c|c|c|c|}
\hline $\begin{array}{l}\text { 山ू } \\
0 \\
\text { uै } \\
\text { a }\end{array}$ & 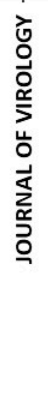 & 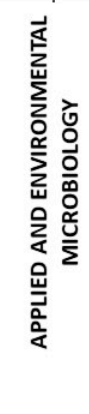 & 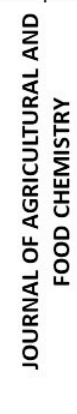 & 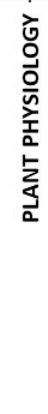 & 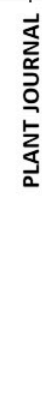 & & 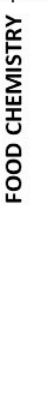 & 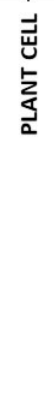 & 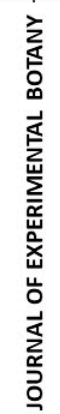 & 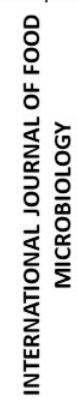 & 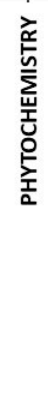 & 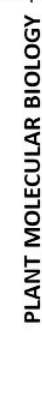 & & & 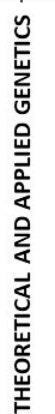 & 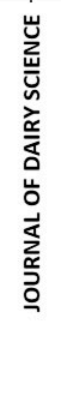 & 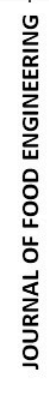 & & & 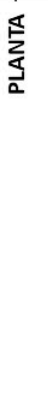 & 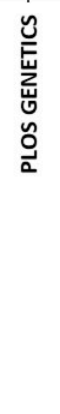 & 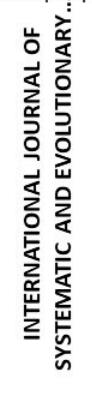 \\
\hline
\end{tabular}

Figure 6. Percentage of articles Field-Weighted Citation Index (FWCI) $\geq 1$, Top 10\% Topic y Topic Cluster.

Together with the FWCI, Figure 4 also shows the percentage of articles in the Top20 journals that are in the Topic and Topic Cluster's Top 10\%. These values are obtained from analysis of the Topic Prominence Percentile and the Topic Cluster Prominence Per-centile, showing the percentage of publications with a percentile equal to or greater than $90 \%$ (first decile).

If the analysis is focused on the Top $10 \%$ Topic, the highest value is reached by Plant Journal, with $81.2 \%$ of its articles placing in the Top 10\%, followed by International Journal of Food Microbiology (76.8\%) and Plant Cell (73.9\%). The lowest value is seen for Theoretical and Applied Genetics, with 32.4\%. If the Topic Clusters are considered, in the top $10 \%$ for the three highest values is Plant Cell, with $65.1 \%$ of its publications, Plant Journal, with 60, and Plant Physiology, with 55.4\%. The lowest value is again found in Theoretical and Applied Genetics, with 13.8\%.

\subsection{The Open Access and European Funding Agencies}

In this section an analysis is made of the publications that have been funded by European programs and of those that are open access, always within the field of study.

There are different types of open access, commonly referred to as open access "routes" or "pathways". Gold Open Access allows free access to the final article, as published, and can be used in accordance with the conditions established by the license of use. The second option is Green Open Access, where the final reader will also have access to the final article. The difference between these two types is that through the first option (Gold Open Access) the deposit and therefore access to the article is made through an open access journal with peer review and generally upon a fee for Article Publishing Charge (APC). In the second way (Green Open Access), the author deposits the article, once accepted (postprint) or an unreviewed article (preprint), in a website or digital resource repository, without having to pay an APC, although a period of embargo is usually imposed by the journal in which the full text cannot be accessed, a period of time that can oscillate between 6 and 
24 months. In addition to these two routes, there is a third route, Bronze Open Access, in which full text articles are accessible from the editor's website but cannot be reused as authors do not have a license to do so. There is also a fourth type, which we can call hybrid (Hybrid Open Access), which refers to hybrid open access journals, in which there are both subscription and open access arti-cles; in this case, the author pays for open access publication. Finally, there is a fifth way, the diamond route, which generally comprises journals from government institutions or scientific associatio ns, which publish open access without payment by the author.

In the Agricultural and Biological Sciences category, 3288 publications were found, funded by both EU and member country research programs. This is less than $12 \%$ of the total. Of these, 548 publications appear to be funded by the EU, through its various research programs discussed above, i.e., $17 \%$ of those funded through some form of research program. In summary, EU-funded research accounts for $2 \%$ of all published work.

An analysis of the papers in OA shows that, among the 548 papers funded by the EU, 399 are not in OA, i.e., $73 \%$. Of these, for those that are OA, i.e., 149, 23 are in OA Gold, 93 in OA Green, 24 in OA Bronze, and 9 in OA Hybrid.

This section highlights the low impact on the number of scientific publications that the EU's research programs have had in the Agricultural and Biological Sciences category, in relation to being cited in patents, as they have formed $2 \%$ of the total number of published papers. Only $27 \%$ of the funded papers have been in some form of OA.

\subsection{Topics of the Publications Cited in Patents}

The topics covered for all these publications can be summarized in two fields: Topic Cluster name, and Topic name. Table 3 shows the first 20 Topic Cluster names and Topic names.

Table 3. Top 20 Topic Cluster names and Topic names.

\begin{tabular}{cc}
\hline Topic Cluster Name & N \\
\hline Arabidopsis, Plants, Genes & 2464 \\
Cheeses, Caseins, Milk & 905 \\
Metagenome, Probiotics, Bacteria & 858 \\
Breads, Starch, Glutens & 574 \\
Viruses, Mosaic Viruses, Phytoplasma & 423 \\
Tea, Polyphenols, Anthocyanins & 388 \\
HIV-1, HIV, HIV Infections & 368 \\
Wines, Vitis, Grapes & 347 \\
Cellulose, Lignin, Cellulases & 344 \\
Shoots, Explants, Callus & 313 \\
Ethylenes, Apples, Fruit & 289 \\
Olea, Oils, Oils and Fats & 284 \\
Drying, Moisture Determination, Thermal Processing (Foods) & 278 \\
Broiler Chickens, Laying Hens, Swine & 275 \\
Spermatozoa, Semen, Oocytes & 269 \\
Plants, Rhizosphere, Rhizobium & 263 \\
Adenoviridae, Neoplasms, Dependovirus & 253 \\
Hepacivirus, Hepatitis B Virus, Hepatitis C & 251 \\
\hline Photosystem II Protein Complex, Photosynthesis, Chlorophyll & 251 \\
\hline
\end{tabular}

There are many genetic issues in the main topic cluster names. Gene-expression analysis is increasingly important in biological research related to plant breading. It is therefore not surprising that the most relevant topic cluster name is, Arabidopsis, Plants, Genes. Arabidopsis thaliana is a small weed of the cruciferous family that has become one of the most important systems for the study of many aspects of plant biology [78]. Its unique characteristics offer several advantages when considering it as a research model. Firstly, it is a true diploid with a very short life cycle (6-8 weeks), of self-pollination, and produces 
numerous seeds that remain viable for many years [79]. Its rapid growth allows the analysis of many individuals in a minimum space and therefore, the consequent rapid amplification of the genotypes useful for later studies [80]. Secondly, its compact genome with relatively few repeated sequences and a low DNA content [81], makes it by far the smallest known genome higher plant, and therefore an ideal system for genetic and molecular studies. Thirdly, it can be transformed by Agrobacterium tumefaciens and through the Ti plasmid it is possible to introduce genes of interest and keep them stable [82].

The second relevant topic cluster name related to genetics is Metagenome, Probiotics, Bacteria. Metagenomics is a set of techniques used to determine the microbial population that can be found in each environment, studied in the community context [83].

It is interesting to note the large number of topic cluster names related to food and nutritional properties: Cheeses-Caseins- Milk; Breads-Starch-Glutens; Tea-PolyphenolsAnthocyanins; or Olea- Oils-Oils and Fats. The consumer is increasingly demanding and directly influences the supply and demand for dairy products, demanding higher quality products. They choose between the lipid and protein components of milk and those present in cheese, such as fatty acids, caseins, and whey proteins. The Food Industry usually seeks to increase milk protein, especially casein, which is considered to be the best quality [84]. Likewise, the growing demand for gluten-free products has encouraged the design of many gluten-free bakery products [85]. Regarding to polyphenols, phenolic compounds are mainly considered to be responsible for the main organoleptic features of foods and beverages of plant origin, particulaly their color and taste properties. They also contribute to health and are associated with the consumption of diets high in fruit and vegetables or drinks of vegetable origin such as wine or tea [86]. Much research highlights the beneficial health effects of the Mediterranean diet, which is distinguished by the consumption of virgin olive oil as the main source of dietary fat [87], of course this is linked to the olive orchard (Olea europaea).

Another of the Topic Cluster names related to food is that of Wines, Vitis, Grapes. It is not surprising that the organoleptic qualities of wine are the subject of major studies given the high economic value of this industry. The final taste of wine is influenced by many factors, but perhaps the most decisive ones are on the one hand the variety of grape used as raw material, and in this regard, there is a market trend towards monovarietal wines, and on the other hand the species of wine yeast used, as each species of wine yeast performs a specific metabolic activity, and therefore determines the final concentrations of flavor compounds in the final wine. Of the studies cited in patents, it is worth highlighting the one related to the quantitative determination of the odorants of fifty-two young red wines from different grape varieties: Garnacha, Tempranillo, Cabernet Sauvignon and Merlot [88]. Another important study is related to the function of yeast species and strains in wine flavor [89].

Finally, another food-related topic cluster name is Drying, Moisture Determination, Thermal Processing (Foods). Of the most cited papers in this field, two are reviews. The first is related to the phenomenon of shrinkage of foodstuffs observed during different dehydration processes [90], and the other to with thermal pasteurization, which is known to be used to reduce microbial populations in foods, but which has the disadvantage of destroying heat-sensitive nutrients and food qualities such as taste, color, and texture [91]. However, research papers in this field highlight studies in food processing and the preservation of ultrasound techniques [92], and those related to the mentioned technique and the interesting compounds of the grape (bioactive substances such as anthocyanins) [93].

The topic names are more specific and, therefore, less numerous in terms of their ap-pearance, but it is interesting to indicate to which Topic Cluster name they belong, as shown in Table 4. It can be verified that among the 20 most important topic names, seven are from the Topic Cluster name of Arabidopsis, Plants, Genes. On the other hand, two are from the second most important Topic Cluster name, "Cheeses, Caseins, Milk" and an-other two from the third "Metagenome, Probiotics, Bacteria". 
Table 4. Top 20 Topic names.

\begin{tabular}{ccc}
\hline Topic Name & N & Topic Cluster Name \\
\hline Cinnamyl Alcohol Dehydrogenase, Lignification, 4-Coumarate-Coa Ligase & 123 & Arabidopsis, Plants, Genes \\
Virgin Olive Oil, Oleuropein, Elenolic Acid & 121 & Olea, Oils, Oils and Fats \\
Nicotiana Benthamiana, Taliglucerase Alfa, Molecular Farming & 107 & Viruses, Mosaic Viruses, Phytoplasma \\
Hepatitis C Virus, Virus Internalization, RNA Replication & 102 & Hepacivirus, Hepatitis B Virus, Hepatitis C \\
Lactobacillus Amylovorus, Bifidobacterium Animalis, Probiotic Agent & 95 & Metagenome, Probiotics, Bacteria \\
Endoreduplication, Arabidopsis, Leaf Growth & 89 & Arabidopsis, Plants, Genes \\
Immunologic Receptors, Passalora Fulva, Plant Immunity & 84 & Arabidopsis, Plants, Genes \\
Anthocyanins, Chalcone Isomerase, Dihydroflavanol 4-Reductase & 83 & Arabidopsis, Plants, Genes \\
Rennet, Milk Protein Concentrate, Caseins & 79 & Cheeses, Caseins, Milk \\
Glucose-1-Phosphate Adenylyltransferase, Starch Synthase, Endosperm & 73 & Breads, Starch, Glutens \\
Glucosinolates, Neoglucobrassicin, Glucoerucin & 72 & Glucosinolates, NF-E2-Related Factor 2, \\
Coffee Beans, Coffea Arabica, Melanoidins & Brassica \\
Bacteriocins, Lactobacillales, Biopreservatives & 71 & Coffee, Caffeine, Energy Drinks \\
Gynoecium, Flowering, Carpels & 68 & Metagenome, Probiotics, Bacteria \\
Strigolactones, Orobanche, Striga Hermonthica & 68 & Arabidopsis, Plants, Genes \\
Arabidopsis, Plants, Genes \\
Neutralizing Antibodies, Human Immunodeficiency Virus Vaccine, GP 140 & 67 & HIV-1, HIV, HIV Infections \\
Adenoviridae, Adenovirus Receptor, Human Adenoviruses & 64 & Adenoviridae, Neoplasms, Dependovirus \\
Peptidyl-Dipeptidase A, Protein Hydrolysates, Antihypertensive Effect & 64 & Cheeses, Caseins, Milk \\
Pulsed Electric Fields, Pasteurization, Heat Inactivation & 64 & Drying, Moisture Determination, Thermal \\
Systemic Acquired Resistance, S-Methyl & Processing (Foods)
\end{tabular}

If an analysis is made by the individual words of the Topic Cluster name and Topic name, Table 5 is obtained. The topic clusters include those related to genetics or molecular biology, such as Genes, Arabidopsis, Metagenome, Genome. Additionally, there are related to specific foods such as Cheeses, Milk, Breads or Oils. The third group can be understood as covering food related constituents such as Caseins, Probiotics, Glutens, or Starch. It is noteworthy that there is a Topic Cluster name of specific animals, i.e., swine. Regarding the Topic names, food issues predominate, especially those related to dairy products such as Probiotic Agent, Lactobacillales, Rennet, Pasteurization, or those related to cereals such as Dough or Glutens.

Table 5. Main words for the top 20 Topic Cluster names and Topic names.

\begin{tabular}{|c|c|c|c|}
\hline Topic Cluster Name & $\mathbf{N}$ & Topic Name & $\mathbf{N}$ \\
\hline Genes & 2907 & Arabidopsis & 500 \\
\hline Plants & 2841 & Probiotic Agent & 267 \\
\hline Arabidopsis & 2464 & Lactobacillales & 204 \\
\hline Neoplasms & 1504 & Nicotiana Benthamiana & 166 \\
\hline Bacteria & 1027 & Virus Internalization & 142 \\
\hline Caseins & 905 & Rennet & 138 \\
\hline Cheeses & 905 & Dough & 135 \\
\hline Milk & 905 & Hepatitis C Virus & 135 \\
\hline Metagenome & 858 & Carotenoids & 132 \\
\hline Probiotics & 858 & Endosperm & 129 \\
\hline Genome & 722 & Anthocyanins & 127 \\
\hline Viruses & 672 & 4-Coumarate-Coa Ligase & 125 \\
\hline Glutens & 620 & Pasteurization & 125 \\
\hline Breads & 574 & Cinnamyl Alcohol Dehydrogenase & 123 \\
\hline Starch & 574 & Lignification & 123 \\
\hline Escherichia Coli & 562 & Elenolic Acid & 121 \\
\hline Oils & 482 & Virgin Olive Oil & 121 \\
\hline Swine & 481 & Agrobacterium & 121 \\
\hline Mosaic Viruses & 423 & Plant Immunity & 120 \\
\hline Phytoplasma & 423 & Glutens & 119 \\
\hline
\end{tabular}




\section{Conclusions}

This paper provides a comprehensive analysis of the current approach to research in the agricultural and biological sciences from the perspective of technology innovation transfer, using patent citation of scientific output as an indicator. This type of approach is encompassed within the Triple Helix concept, where the efforts of academia, industry and governments are brought together.

The great challenge of agriculture, as an economic activity, and of agronomy, as a science, is to provide food for the world's population. The European Union is a geographically densely inhabited area with a long tradition of agricultural research. In the 1999-2019 period, almost one million papers were published by the EU-27 countries in Agri-cultural and Biological Sciences category. Since 2013, these publications stabilized at around 650,000 per year. Only $2.8 \%$ of these publications have been cited by patents. That is about 1700 per year, decreasing in the last 10 years; this is the estimated period of the impact of scientific production on patents. These papers have had an average of six au-thors. Review articles have accounted for $7 \%$, when, in this scientific field as a whole, they account for $3.4 \%$.

The systematic benchmarking of results is necessary to help take steps towards improving one's own scientific activity, in order to collect information and to develop a framework for the future. In addition, this allows the concepts on which the evaluation of academic performance or publications is based, i.e., benchmarking based on indicators, to identify best practices for the improvement of the initial situation. Therefore, for further benchmarking purposes, the main results are shown below as an initial framework.

The results validate the relevance of applying bibliometric indicators to a patent. Forty percent of this research was carried out in collaboration with 130 countries outside the EU-27. This certainly shows the great collaboration that exists between the EU-27 coun-tries and the rest of the world. The top five countries in this regard are Germany, France, Spain, Italy, and the Netherlands. The institutions that lead the research cited in patents are the central research institutions of the countries mentioned above: CNRS (France), INRAE (Italy), or CSIC (Spain). This is probably due to the large volume of scientific pro-duction that these institutions have. If attention is paid to the degree of specialization of the institutions, understood as the percentage of articles in the Agricultural and Biological Sciences category in relation to the total number of published works, there are three institutions with more than $30 \%$; these are the Swedish University of Agricultural Sciences (58\%), AgroParisTech (52\%), Wageningen University \& Research (48\%), and INRAE (38\%).

The journals used for this scientific production are mainly indexed in the SJR Plant Science, and Genetics categories, followed by Food Science. According to the JCR classification, they would also be classified under Plant Science, and Food Science \& Technology. A total of $90 \%$ of the published articles equaled or exceeded the FWCI's benchmark 1; this means that the articles have had a higher-than-expected citation level for the year of pub-lication, the type of publication and the discipline in which they are categorized. If the analysis is focused on the top $10 \%$ Topic, the highest value is reached by Plant Journal, with $81.2 \%$ of its articles placed in the top $10 \%$, followed by International Journal of Food Microbiology (76.8\%) and Plant Cell (73.9\%).

This manuscript highlights the low impact that the EU's research programs have had on the number of scientific publications in the Agricultural and Biological Sciences category, in relation to being cited in patents, as they have formed $2 \%$ of the total number of published papers. Only $27 \%$ of the funded papers were in some form of OA.

The top three Topic Cluster names were: "Arabidopsis, Plants, Genes", "Cheeses, Caseins, Milk", and "Metagenome, Probiotics, Bacteria". The top three Topic names were: "Cinnamyl Alcohol Dehydrogenase, Lignification, 4-Coumarate-Coa Ligase", "Virgin Olive Oil, Oleuropein, Elenolic Acid", and "Nicotiana Benthamiana, Taliglucerase Alfa, Molecular Farming".

In summary, the research topics most reflected in patents are those related to genetics (Arabidopsis, Metagenome, Genome), to major food issues (Cheeses, Milk, Breads or Oils 
and to food and beverage products that are of great concern at present (Caseins, Probiotics, Glutens, or Starch).

The use of patents for decision-making is not yet a widespread tool on all innovative research fronts; this work can be a benchmark for future policy decisions regarding the directions research institutions should take in their future development. The results provide evidence of the potential of the methodology developed and the metrics obtained to represent the patent transfer contributions of national science systems as an indicator of technological innovation.

From this point of view, the current strategic research plan of both the EU-27 and its member countries' systems should seek to enhance the development of the science base for an industry based on the transfer to industry. Transfer to patents has proven to be long-term, and university rankings and demands on researchers are short-term. Trying to link the two issues would improve the search for innovations for industry itself, which, in the end, would translate into an improvement in the quality of life of citizens.

Author Contributions: M.C. and A.A. conceived and wrote the article; A.A. and E.S.-M. analyzed the data; M.C., A.A. and F.M.-A. wrote the paper. A.A. and F.M.-A. supervised the research. E.S.-M. and F.M.-A. revised the manuscript. They share the structure and aims of the manuscript, paper drafting, editing and review. All authors have read and agreed to the published version of the manuscript.

Funding: This research received no external funding.

Institutional Review Board Statement: Not applicable.

Informed Consent Statement: Not applicable.

Data Availability Statement: Data retrieved from Scopus, SciVal, JCR, and SJR databases.

Acknowledgments: The authors would like to thank to the CIAIMBITAL (University of Almeria, CeiA3) for its support.

Conflicts of Interest: The authors declare no conflict of interest.

\section{References}

1. Doré, T.; Makowski, D.; Malézieux, E.; Munier-Jolain, N.; Tchamitchian, M.; Tittonell, P. Facing up to the paradigm of ecological intensification in agronomy: Revisiting methods, concepts and knowledge. Eur. J. Agron. 2011, 34, 197-210. [CrossRef]

2. Ericksen, P. Conceptualizing food systems for global environmental change research. Glob. Environ. Chang. 2008, 18, 234-245. [CrossRef]

3. Gattullo, C.E.; Mezzapesa, G.N.; Stellacci, A.M.; Ferrara, G.; Occhiogrosso, G.; Petrelli, G.; Castellini, M.; Spagnuolo, M. Cover Crop for a Sustainable Viticulture: Effects on Soil Properties and Table Grape Production. Agronomy 2020, 10, 1334. [CrossRef]

4. Tilman, D.; Cassman, K.G.; Matson, P.A.; Naylor, R.; Polasky, S. Agricultural sustainability and intensive production practices. Nature 2002, 418, 671-677. [CrossRef]

5. Ahmad, N.; Mukhtar, Z. Genetic manipulations in crops: Challenges and opportunities. Genomics 2017, 109, 494-505. [CrossRef] [PubMed]

6. Poudel, S.; Poudel, B.; Acharya, B.; Poudel, P. Pesticide use and its impacts on human health and environment. Environ. Ecosyst. Sci. 2020, 4, 47-51. [CrossRef]

7. Laraus, J. The problems of sustainable water use in the Mediterranean and research requirements for agriculture. Ann. Appl. Biol. 2004, 144, 259-272. [CrossRef]

8. Baranski, M.R. Wide adaptation of Green Revolution wheat: International roots and the Indian context of a new plant breeding ideal, 1960-1970. Stud. Hist. Philos. Sci. Part C 2015, 50, 41-50. [CrossRef]

9. Roesch-McNally, G.E.; Basche, A.D.; Arbuckle, J.; Tyndall, J.C.; Miguez, F.E.; Bowman, T.; Clay, R. The trouble with cover crops: Farmers' experiences with overcoming barriers to adoption. Renew. Agric. Food Syst. 2018, 33, 322-333. [CrossRef]

10. Zapata-Sierra, A.J.; Manzano-Agugliaro, F. Controlled deficit irrigation for orange trees in Mediterranean countries. J. Clean. Prod. 2017, 162, 130-140. [CrossRef]

11. La Malfa, G.; Leonardi, C. Crop practices and techniques: Trends and needs. Acta Hortic. 2001, 1, 31-42. [CrossRef]

12. Pertot, I.; Caffi, T.; Rossi, V.; Mugnai, L.; Hoffmann, C.; Grando, M.S.; Gary, C.; Lafond, D.; Duso, C.; Thiery, D.; et al. A critical review of plant protection tools for reducing pesticide use on grapevine and new perspectives for the implementation of IPM in viticulture. Crop. Prot. 2017, 97, 70-84. [CrossRef]

13. Berk, P.; Hocevar, M.; Stajnko, D.; Belsak, A. Development of alternative plant protection product application techniques in orchards, based on measurement sensing systems: A review. Comput. Electron. Agric. 2016, 124, 273-288. [CrossRef]

14. Sanders, K. Orange Harvesting Systems Review. Biosyst. Eng. 2005, 90, 115-125. [CrossRef] 
15. Méndez, V.; Pérez-Romero, A.; Sola-Guirado, R.R.; Miranda-Fuentes, A.; Manzano-Agugliaro, F.; Zapata-Sierra, A.; RodríguezLizana, A. In-Field Estimation of Orange Number and Size by 3D Laser Scanning. Agronomy 2019, 9, 885. [CrossRef]

16. Novas, N.; Alvarez-Bermejo, J.; Valenzuela, J.L.; Gázquez, J.; Manzano-Agugliaro, F. Development of a smartphone application for assessment of chilling injuries in zucchini. Biosyst. Eng. 2019, 181, 114-127. [CrossRef]

17. El Khaled, D.; Novas, N.; Gazquez, J.A.; Garcia, R.M.; Manzano-Agugliaro, F. Fruit and Vegetable Quality Assessment via Dielectric Sensing. Sensors 2015, 15, 15363-15397. [CrossRef]

18. Manzano-Agugliaro, F.; García-Cruz, A.; Fernández-Sánchez, J.S. Women's labour and mechanization in mediter-ranean greenhouse farming. Outlook Agric. 2013, 42, 249-254.

19. Welch, R.M.; Graham, R.D. A new paradigm for world agriculture: Meeting human needs: Productive, sustainable, nutritious. Field Crop. Res. 1999, 60, 1-10. [CrossRef]

20. Ruiz-Real, J.L.; Uribe-Toril, J.; Arriaza, J.A.T.; Valenciano, J.D.P. A Look at the Past, Present and Future Research Trends of Artificial Intelligence in Agriculture. Agronomy 2020, 10, 1839. [CrossRef]

21. Olesen, J.; Trnka, M.; Kersebaum, K.; Skjelvåg, A.; Seguin, B.; Peltonensainio, P.; Rossi, F.; Kozyra, J.; Micale, F. Impacts and adaptation of European crop production systems to climate change. Eur. J. Agron. 2011, 34, 96-112. [CrossRef]

22. Pretty, J. Intensification for redesigned and sustainable agricultural systems. Science 2018, 362, eaav0294. [CrossRef] [PubMed]

23. Van Etten, J.; Beza, E.; Calderer, L.; Van Duijvendijk, K.; Fadda, C.; Fantahun, B.; Kidane, Y.G.; Van De Gevel, J.; Gupta, A.; Mengistu, D.K.; et al. First experiences with a novel farmer citizen science approach: Crowdsourcing participatory variety selection through on-farm triadic comparisons of technologies (tricot). Exp. Agric. 2016, 55, 275-296. [CrossRef]

24. Li, X.; Gagliardi, D.; Miles, I. Variety in the innovation process of UK research and development service firms. RD Manag. 2019, 50, 173-187. [CrossRef]

25. Van Norman, G.A.; Eisenkot, R. Technology transfer: From the research bench to commercialization: Part 1: Intel-lectual property rights-Basics of patents and copyrights. JACC Basic Transl. Sci. 2017, 2, 85-97. [CrossRef]

26. Blind, K. The influence of regulations on innovation: A quantitative assessment for OECD countries. Res. Policy 2012, 41, 391-400. [CrossRef]

27. Di Cataldo, V. From the European patent to a community patent. Colum. J. Eur. Law 2002, 8, 19.

28. Schäfers, A. The Luxembourg Patent Convention, The Best Option for the Internal Market. JCMS J. Common. Mark. Stud. 1987, 25, 193-207. [CrossRef]

29. Deng, Y. The effects of patent regime changes: A case study of the European patent office. Int. J. Ind. Organ. 2007, 25, 121-138. [CrossRef]

30. Heikkilä, J.T.; Verba, M.A. The role of utility models in patent filing strategies: Evidence from European countries. Science 2018, 116, 689-719. [CrossRef]

31. Brack, H.P. Utility Models and Their Comparison with Patents and Implications for the US Intellectual Property Law System. Boston College Intellectual Property and Technology Forum. 2009, pp. 1-15. Available online: http://bciptf.org/wp-content/ uploads/2011/07/13-iptf-Brack.pdf (accessed on 29 January 2021).

32. Moser, P. How do patent laws influence innovation? Evidence from nineteenth-century world's fairs. Am. Econ. Rev. 2005, 95, 1214-1236. [CrossRef]

33. Guimón, J. Promoting university-industry collaboration in developing countries. World Bank 2013, 3, $12-48$.

34. Galvez-Behar, G. The 1883 Paris Convention and the Impossible Unification of Industrial Property. In Patent Cultures; Cambridge University Press (CUP): Cambridge, UK, 2021; pp. 38-68.

35. Blakeney, M. Patenting of plant varieties and plant breeding methods. J. Exp. Bot. 2012, 63, 1069-1074. [CrossRef]

36. Enghardt, F.; Hekker, F. The Trade Mark Reform Package and the classification of goods and services. J. Intellect. Prop. Law Pract. 2016, 11, 822-825. [CrossRef]

37. Kiewiet, B. Plant variety protection in the European Community. World Pat. Inf. 2005, 27, 319-327. [CrossRef]

38. Pisoschi, A.M.; Pisoschi, C.G. Is open access the solution to increase the impact of scientific journals? Science 2016, 109, 1075-1095. [CrossRef]

39. Leydesdorff, L.; Meyer, M. The decline of university patenting and the end of the Bayh-Dole effect. Science 2010, 83, 355-362. [CrossRef]

40. Watanabe, C.; Tsuji, Y.S.; Griffy-Brown, C. Patent statistics: Deciphering a 'real'versus a 'pseudo'proxy of innovation. Technovation 2001, 21, 783-790. [CrossRef]

41. Zhang, T.; Chen, J.; Jia, X. Identification of the Key Fields and Their Key Technical Points of Oncology by Patent Analysis. PLoS ONE 2015, 10, e0143573. [CrossRef]

42. Kuan, C.-H.; Huang, M.-H.; Chen, D.-Z. Ranking patent assignee performance by h-index and shape descriptors. J. Inf. 2011, 5, 303-312. [CrossRef]

43. Luan, C.; Zhou, C.; Liu, A. Patent strategy in Chinese universities: A comparative perspective. Science 2010, 84, 53-63. [CrossRef]

44. Kang, K.; Sohn, S.Y. Evaluating the patenting activities of pharmaceutical research organizations based on new technology indices. J. Inf. 2016, 10, 74-81. [CrossRef]

45. Bornmann, L.; Mutz, R.; Daniel, H.-D. Are there better indices for evaluation purposes than the h index? A comparison of nine different variants of the $\mathrm{h}$ index using data from biomedicine. J. Am. Soc. Inf. Sci. Technol. 2008, 59, 830-837. [CrossRef] 
46. Diaz Perez, M.; Rivero Amador, S.; de Moya-Anegon, F. Latin American technological production of greatest in-ternational visibility. 1996-2007. A case study: Brasil. Rev. Española Doc. Científica 2010, 33, 34-62.

47. Makhoba, X.; Pouris, A. A patentometric assessment of selected R\&D priority areas in South Africa, a comparison with other BRICS countries. World Pat. Inf. 2019, 56, 20-28. [CrossRef]

48. Díaz-Pérez, M.; De-Moya-Anegón, F. El análisis de patentes como estrategia para la toma de decisiones innovadoras, El Profesional de la Información. Prof. Inf. 2008, 17, 293-302.

49. Noruzi, A.; Abdekhoda, M. Google Patents: The global patent search engine. Webology 2014, 11, 1-12.

50. Moskovkin, V.M.; Shigorina, N.A.; Popov, D. The possibility of using the Google Patents search tool in patentometric analysis (based on the example of the world's largest innovative companies). Sci. Tech. Inf. Process. 2012, 39, 107-112. [CrossRef]

51. Huang, M.H.; Dong, H.R.; Chen, D.Z. Globalization of collaborative creativity through cross-border patent activities. J. Informetr. 2012, 6, 226-236. [CrossRef]

52. Huang, M.-H.; Chen, S.-H.; Lin, C.-Y.; Chen, D.-Z. Exploring temporal relationships between scientific and technical fronts: A case of biotechnology field. Science 2013, 98, 1085-1100. [CrossRef]

53. Motta, G.D.S.; Quintella, R.H. Assessment of Non-Financial Criteria in the Selection of Investment Projects for Seed Capital Funding: The Contribution of Scientometrics and Patentometrics. J. Technol. Manag. Innov. 2012, 7, 172-197. [CrossRef]

54. Park, H.W.; Hong, H.D.; Leydesdorff, L. A comparison of the knowledge-based innovation systems in the economies of South Korea and the Netherlands using Triple Helix indicators. Science 2005, 65, 3-27. [CrossRef]

55. Etzkowitz, H.; Leydesdorff, L. The dynamics of innovation: From National Systems and "Mode 2" to a Triple Helix of universityindustry-government relations. Res. Policy 2000, 29, 109-123. [CrossRef]

56. Meyer, M.S.; Siniläinen, T.; Utecht, J.T. Towards hybrid Triple Helix indicators: A study of university-related patents and a survey of academic inventors. Science 2003, 58, 321-350. [CrossRef]

57. Baldini, N. University patenting and licensing activity: A review of the literature. Res. Eval. 2006, 15, 197-207. [CrossRef]

58. Kim, H.; Huang, M.; Jin, F.; Bodoff, D.; Moon, J.; Choe, Y.C. Triple helix in the agricultural sector of Northeast Asian countries: A comparative study between Korea and China. Science 2011, 90, 101-120. [CrossRef]

59. Chihib, M.; Salmerón-Manzano, E.; Novas, N.; Manzano-Agugliaro, F. Bibliometric Maps of BIM and BIM in Uni-versities: A Comparative Analysis. Sustainability 2019, 11, 4398. [CrossRef]

60. Garrido-Cardenas, J.A.; Esteban-García, B.; Agüera, A.; Pérez, J.A.S.; Manzano-Agugliaro, F. Wastewater Treatment by Advanced Oxidation Process and Their Worldwide Research Trends. Int. J. Environ. Res. Public Health 2019, 17, 170. [CrossRef]

61. Garrido-Cardenas, J.A.; González-Cerón, L.; Manzano-Agugliaro, F.; Mesa-Valle, C. Plasmodium genomics: An approach for learning about and ending human malaria. Parasitol. Res. 2019, 118, 1-27. [CrossRef]

62. Garrido-Cardenas, J.A.; Mesa-Valle, C.; Manzano-Agugliaro, F. Human parasitology worldwide research. Parasitology 2017, 145, 699-712. [CrossRef]

63. Binfield, P. Novel Scholarly Journal Concepts. In Opening Science. The Evolving Guide on How the Internet Is Changing Research, Collaboration and Scholarly Publishing; Bartling, S., Friesike, S., Eds.; Springer: Cham, Switzerland, 2014; pp. 155-163. ISBN 978 3 319000268.

64. Colledge, L. Output and outcome metrics. In Snowball Metrics Recipe Book; Colledge, L., Ed.; Elsevier: Amsterdam, The Netherlands, 2017; p. 87. Available online: www.snowballmetrics.com/ (accessed on 21 January 2021).

65. Li, B.; Ch'Ng, E.; Chong, A.Y.-L.; Bao, H. Predicting online e-marketplace sales performances: A big data approach. Comput. Ind. Eng. 2016, 101, 565-571. [CrossRef]

66. Li, R.-T.; Khor, K.A.; Yu, L. Identifying Indicators of Progress in Thermal Spray Research Using Bibliometrics Analysis. J. Therm. Spray Technol. 2016, 25, 1526-1533. [CrossRef]

67. Yu, M.-C.; Wu, Y.J.; Alhalabi, W.; Kao, H.-Y.; Wu, W.-H. ResearchGate: An effective altmetric indicator for active researchers? Comput. Hum. Behav. 2016, 55, 1001-1006. [CrossRef]

68. Ekpo, E.; Hogg, P.; McEntee, M. A Review of Individual and Institutional Publication Productivity in Medical Radiation Science. J. Med. Imaging Radiat. Sci. 2016, 47, 13-20. [CrossRef]

69. Avanesova, A.A.; Shamliyan, T.A. Comparative trends in research performance of the Russian universities. Science 2018, 116, 2019-2052. [CrossRef]

70. Liu, X.; Sun, R.; Wang, S.; Wu, Y.J. The research landscape of big data: A bibliometric analysis. Libr. Hi Tech. 2019, 38, 367-384. [CrossRef]

71. Colledge, L. SciVal. Usage and Patent Metrics. Guidebook. 2019. Available online: https://p.widencdn.net/1ldn6j/ACAD_SV_ EB_SciValUsageandPatentGuide_WEB (accessed on 21 January 2021).

72. Zijlstra, H.; McCullough, R. CiteScore: A New Metric to Help You Track Journal Performance and Make Decisions; Elsevier: Amsterdam, The Netherlands, 2016. Available online: https:/ / www.elsevier.com/editors-update/story/journal-metrics/citescore-a-newmetric-to-help-you-choose-the-right-journal (accessed on 21 January 2021).

73. Garfield, E. Citation Indexes for Science: A New Dimension in Documentation through Association of Ideas. Science 1955, 122, 108-111. [CrossRef]

74. Larivière, V.; Sugimoto, C.R. The Journal Impact Factor: A Brief History, Critique, and Discussion of Adverse Effects. In Springer Handbook of Science and Technology Indicators; Moed, H., Schmoch, U., Thelwall, E., Glänzel, W., Eds.; Springer: Berlin/Heidelberg, Germany, 2019. 
75. González-Pereira, B.; Guerrero-Bote, V.; Moya-Anegón, F. A new approach to the metric of journals' scientific prestige: The SJR indicator. J. Inf. 2010, 4, 379-391. [CrossRef]

76. Bergstrom, C.T.; West, J. Comparing Impact Factor and Scopus CiteScore. Eigenfactor.org. 2016. Available online: http: / / eigenfactor.org/projects/posts/citescore.php (accessed on 21 January 2021).

77. Elsevier. Research Metrics GuidebookResearch Intelligence. 2019. Available online: https://p.widencdn.net/5pyfuk/ACAD_ RL_EB_ElsevierResearchMetricsBook_WEB (accessed on 21 January 2021).

78. Meyerowitz, E.M. Arabidopsis thaliana. Annu. Rev. Genet. 1987, 21, 93-111.

79. Czechowski, T.; Stitt, M.; Altmann, T.; Udvardi, M.K.; Scheible, W. Genome-Wide Identification and Testing of Superior Reference Genes for Transcript Normalization in Arabidopsis. Plant Physiol. 2005, 139, 5-17. [CrossRef]

80. Schmid, M.; Davison, T.S.; Henz, S.R.; Pape, U.J.; Demar, M.; Vingron, M.; Schölkopf, B.; Weigel, D.; Lohmann, J.U. A gene expression map of Arabidopsis thaliana development. Nat. Genet. 2005, 37, 501-506. [CrossRef] [PubMed]

81. Leutwiler, L.S.; Hough-Evans, B.R.; Meyerowitz, E.M. The DNA of Arabidopsis thaliana. Mol. Genet. Genom. 1984, 194, 15-23. [CrossRef]

82. Lloyd, A.M.; Barnason, A.R.; Rogers, S.G.; Byrne, M.C.; Fraley, R.T.; Horsch, R.B. Transformation of Arabidopsis thaliana with Agrobacterium tumefaciens. Science 1986, 234, 464-466. [CrossRef] [PubMed]

83. Garrido-Cardenas, J.A.; Manzano-Agugliaro, F. The metagenomics worldwide research. Curr. Genet. 2017, 63, 819-829. [CrossRef] [PubMed]

84. Boukria, O.; El Hadrami, E.M.; Boudalia, S.; Safarov, J.; Leriche, F.; Aït-Kaddour, A. The Effect of Mixing Milk of Different Species on Chemical, Physicochemical, and Sensory Features of Cheeses: A Review. Foods 2020, 9, 1309. [CrossRef]

85. Horstmann, S.W.; Lynch, K.M.; Arendt, E.K. Starch Characteristics Linked to Gluten-Free Products. Foods 2017, 6, 29. [CrossRef]

86. Cheynier, V. Polyphenols in foods are more complex than often thought. Am. J. Clin. Nutr. 2005, 81, 223S-229S. [CrossRef]

87. Ghanbari, R.; Anwar, F.; Alkharfy, K.M.; Gilani, A.; Li, M. Valuable Nutrients and Functional Bioactives in Different Parts of Olive (Olea europaea L.)-A Review. Int. J. Mol. Sci. 2012, 13, 3291-3340. [CrossRef]

88. Ferreira, V.; Lopez, R.; Cacho, J.F. Quantitative determination of the odorants of young red wines from different grape varieties. J. Sci. Food Agric. 2000, 80, 1659-1667.

89. Romano, P.; Fiore, C.; Paraggio, M.; Caruso, M.; Capece, A. Function of yeast species and strains in wine flavour. Int. J. Food Microbiol. 2003, 86, 169-180.

90. Mayor, L.; Sereno, A. Modelling shrinkage during convective drying of food materials: A review. J. Food Eng. 2004, 61, 373-386. [CrossRef]

91. Garcia-Gonzalez, L.; Geeraerd, A.; Spilimbergo, S.; Elst, K.; Van Ginneken, L.; Debevere, J.; Van Impe, J.; Devlieghere, F. High pressure carbon dioxide inactivation of microorganisms in foods: The past, the present and the future. Int. J. Food Microbiol. 2007, 117, 1-28. [CrossRef] [PubMed]

92. Knorr, D.; Zenker, M.; Heinz, V.; Lee, D.-U. Applications and potential of ultrasonics in food processing. Trends Food Sci. Technol. 2004, 15, 261-266. [CrossRef]

93. Corrales, M.; Toepfl, S.; Butz, P.; Knorr, D.; Tauscher, B. Extraction of anthocyanins from grape by-products assisted by ultrasonics, high hydrostatic pressure or pulsed electric fields: A comparison. Innov. Food Sci. Emerg. Technol. 2008, 9, 85-91. [CrossRef] 